\title{
Archaea in organic-lean and organic-rich marine subsurface sediments: an environmental gradient reflected in distinct phylogenetic lineages
}

\author{
Alan M. Durbin ${ }^{1}$ and Andreas Teske ${ }^{2}$. \\ Department of Ecology and Evolutionary Biology, University of California Irvine, Irvine, CA, USA \\ ${ }^{2}$ Department of Marine Sciences, University of North Carolina at Chapel Hill, Chapel Hill, NC, USA
}

\section{Edited by:}

Virginia P. Edgcomb, Woods Hole

Oceanographic Institution, USA

\section{Reviewed by:}

Peter D. Countway, Bigelow

Laboratory for Ocean Sciences, USA

Julie A. Huber, Marine Biological

Laboratory, USA

\section{*Correspondence:}

Andreas Teske, Department of Marine Sciences, University of North Carolina at Chapel Hill, 3117B Venable Hall, CB 3300, Chapel Hill, NC 27599, USA.

e-mail: teske@email.unc.edu
Examining the patterns of archaeal diversity in little-explored organic-lean marine subsurface sediments presents an opportunity to study the association of phylogenetic affiliation and habitat preference in uncultured marine Archaea. Here we have compiled and reanalyzed published archaeal $16 \mathrm{~S}$ rRNA clone library datasets across a spectrum of sediment trophic states characterized by a wide range of terminal electron-accepting processes. Our results show that organic-lean marine sediments in deep marine basins and oligotrophic open ocean locations are inhabited by distinct lineages of archaea that are not found in the more frequently studied, organic-rich continental margin sediments. We hypothesize that different combinations of electron donor and acceptor concentrations along the organic-rich/organic-lean spectrum result in distinct archaeal communities, and propose an integrated classification of habitat characteristics and archaeal community structure.

Keywords: archaea, marine sediments, oligotrophy, subsurface, phylogeny, uncultured archaea

\section{INTRODUCTION}

Marine sedimentary microbial communities are key mediators of global biogeochemical cycles (e.g., D'Hondt et al., 2002, 2004; Wellsbury et al., 2002). The Domain Archaea accounts for a large portion, perhaps the majority, of deep-subsurface prokaryotic cells and biomass (Biddle et al., 2006; Lipp et al., 2008), and by implication, global biomass (Parkes et al., 1994; Whitman et al., 1998). The majority of studies thus far have focused on relatively organicrich deep-subsurface sediments (e.g., Parkes et al., 1994, 2005; Reed et al., 2002; Wellsbury et al., 2002; D'Hondt et al., 2004; Biddle et al., 2006; Inagaki et al., 2006; Sørensen and Teske, 2006; Kendall et al., 2007; Heijs et al., 2008; Nunoura et al., 2008). However, abyssal sediments $>2000 \mathrm{~m}$ water depth cover a much larger extent of the ocean floor ( $89 \%$; Dunne et al., 2007) and, in contrast to margin or coastal sediments, are generally oligotrophic, with low organic carbon content $(<1 \%)$ and slow rates of deposition (Seiter et al., 2004; Dunne et al., 2007). Electron acceptors such as oxygen or nitrate penetrate these oligotrophic sediments on a scale of meters (D'Hondt et al., 2004) or tens of meters (Gieskes and Boulègue, 1986; D'Hondt et al., 2009), in contrast to organic-rich continental margin or shelf sediments where these strong electron acceptors are used up within centimeters. This expansion of the oxic and nitrate-reducing zone in oligotrophic sediments is a function of the slow rates of carbon deposition and microbial carbon remineralization. The combination of higher-energy electron acceptor type and slower flux of electron donor substrates likely imposes distinct constraints on life in oligotrophic marine sediments, which cover the majority of the surface of Earth.

Several phylum-level uncultured archaeal lineages have been identified as typical deep-subsurface sediment-associated groups (Inagaki et al., 2003, 2006; Parkes et al., 2005; Biddle et al., 2006,
2008; Sørensen and Teske, 2006; Teske and Sørensen, 2008; Fry et al., 2008). These include the Marine Benthic Group B (MBGB, Vetriani et al., 1999), a deeply branching phylum-level lineage; the Miscellaneous Crenarchaeotal Group (MCG, Inagaki et al., 2003), a frequently detected crenarcheotal lineage with high intragroup diversity; the South African Gold Mine Euryarchaeotal Group (SAGMEG, Takai et al., 2001); and the Marine Benthic Group D (MBG-D, Vetriani et al., 1999), a euryarchaeotal group affiliated with the Thermoplasmatales. All of these are approximately phylum-level in divergence, with the exception of the MBG-D, which groups along with the MG-II archaea (DeLong, 1992; Fuhrman et al., 1992) and MG-III archaea (Fuhrman and Davis, 1997) in a well-supported clade affiliated with the Thermoplasmatales (Durbin and Teske, 2011). However, our current datasets on archaeal community composition in deep marine sediments are biased toward organic-rich continental margin sediments (Teske and Sørensen, 2008). Relatively few studies have surveyed the archaeal diversity of abyssal or ocean gyre sediments to date. A more or less comprehensive list includes: Vetriani et al., 1999; Inagaki et al., 2001; Sørensen et al., 2004; Wang et al., 2004; Nercessian et al., 2005; Wang et al., 2005; Xu et al., 2005; Gillan and Danis, 2007; Li et al., 2008; Tao et al., 2008; Roussel et al., 2009; Wang et al., 2010a, Liao et al., 2011; Durbin and Teske, 2010, 2011. Most of these studies are limited to shallow sediments ( $<1 \mathrm{~m}$ deep) or to few depth intervals. Thus, the available database for archaeal communities in oligotrophic marine subsurface sediments has not yet reached the same coverage as eutrophic sediments. Nonetheless, initial datasets from the South Pacific (Durbin et al., 2009; Durbin and Teske, 2010, 2011) and other datasets in the literature point to profoundly different archaeal communities, with little or no overlap at the phylum and subphylum level. 
Examining the patterns of archaeal diversity in little-explored oligotrophic sediments presents an opportunity to study the association of phylogenetic affiliation and habitat preference in uncultured Archaea. We expect a linkage between sediment habitat type and phylogenetic identity, since the distinct physiological demands - sustaining metabolism and growth with low-energy electron acceptors in anaerobic, organic-rich sediments, in contrast to electron donor limitation in oxidized sediments - should select for distinct organisms in organic-lean, oxidized sediments that differ from those in organic-rich, reduced sediments. Specialization in terminal electron acceptors with higher redox potential for a given substrate may differentiate organisms adapted to oxic/suboxic organic-lean environments from those adapted to more organic-rich, typically anoxic environments.

However, an important caveat is that free-energy yield is highly contingent on in situ conditions, possibly subverting the expected hierarchy of electron acceptor energy yields based on standard conditions. Factors such as syntrophy (McInerney and Beaty, 1988), biotic (Wang et al., 2008, 2010b), or abiotic (König et al., 1997, 1999) release from feedback inhibition, pH (Postma and Jakobsen, 1996; Thamdrup, 2000), and substrate competitive release or substrate-pooling (e.g., Lever et al., 2010) may all impact in situ energetics of metabolisms. Additionally, redox niche adaptation likely extends beyond simply the ability to use a particular electron acceptor. In situ redox state $\left(E_{\mathrm{h}}\right)$ determines the thermodynamic favorability of a given biosynthetic pathway, as biosynthetic pathways feasible under highly reduced conditions are less favorable in more oxidized environments; fatty acid biosynthesis (palmitate) is a classic example (McCollom and Amend, 2005). Low substrate concentrations in organic-lean environments may be countered with high-substrate-affinity catabolic enzymes, as in the oligotrophic archaeon Nitrosopumilus maritimus (MartensHabbena et al., 2009). Economical use of electron acceptors with a high redox potential, as shown for ammonia-oxidizing Thaumarchaeota (Schleper and Nicol, 2010), may allow organisms to take advantage of the expanded redox transition zones in organic-lean environments.

With the largely unexplored complexity of organismal redox adaptation noted, we hypothesize that different combinations of electron donor and acceptor concentrations along the organicrich/organic-lean spectrum result in distinct archaeal communities that have optimized their energetic requirements for cell maintenance and growth. This hypothesis article examines published archaeal 16S rDNA clone library datasets across a wide spectrum of sediment trophic states and terminal electron-accepting processes.

\section{SAMPLING SITES}

This study analyses archaeal communities in organic-lean subsurface sediments from the South China Sea (Wang et al., 2010a), the Fairway Basin in the Western Tropical Pacific (Roussel et al., 2009), the Peru Basin offshore Peru (Sørensen et al., 2004), the equatorial upwelling zone west of the Galapagos (Teske, 2006; Teske and Sørensen, 2008), and the South Pacific Subtropical Front northeast of New Zealand (Durbin and Teske, 2011; Table 1; Figure 1). These sediments were contrasted with organic-rich sediments of ODP Leg 201 sites 1227 and 1229, located beneath the highly productive Peruvian upwelling zone, with the methane- clathrate-bearing deep-subsurface sediments of ODP site 1230 in the Peru Trench (Parkes et al., 2005; Biddle et al., 2006; Inagaki et al., 2006; Sørensen and Teske, 2006), and with sediments from the Cascadia Margin offshore Oregon recovered during ODP Leg 204 (Inagaki et al., 2006; Nunoura et al., 2008). ODP Leg 201 Site 1226 south of Galapagos was included as an example of a mesotrophic deep marine sediment, and IODP Expedition 308 sites U1319 and U1320 were included as examples of turbidite continental slope sediments (Nunoura et al., 2009). Methane seep sediments from the Mediterranean provided an example of a deepwater, yet highly reducing shallow sediment environment (Heijs et al., 2008). A phylogenetic and environmental outgroup is provided by sequences from two non-marine anoxic habitats, an anaerobic digestor (Chouari et al., 2005) and rumen (Sundset et al., 2009).

Although geochemical data were incomplete, two sites from the South China Sea (MD05-2896, MD05-2902; Wang et al., 2010a) and several sediment columns from the Coral Sea (ZoNéCo12 sites; Roussel et al., 2009) were included as oligotrophic to mesotrophic sedimentary environments (Table 1; Figure 1) based on nearby ODP sites with complementary geochemistry data. Approx. $195 \mathrm{~km}$ separates ODP Leg 184 Site 1148 and MD05-2902, both are located at similar depths (Site 1148: 3700; MD05-2902: $\sim 3300 \mathrm{~m}$ ) in the Pearl River Basin, Northern South China Sea. ODP Leg 184 Site 1143 and MD05-2896 are separated by $\sim 210 \mathrm{~km}$ within the Dangerous Grounds geologic province of the South China Sea. Although these sites are at significantly different depths (approx. $1650 \mathrm{~m}$ for MD05-2896 and $2770 \mathrm{~m}$ for Site 1143), they share a common sedimentary regime of pelagic drape amid broken carbonate platforms distant from the continental shelf (Hutchison, 2004). Analogs for the ZoNeCo-12 sites in the Fairway Basin south of New Caledonia come from a prior geochemical survey (ZoNéCo-5) of the same marine basin. The sites from these two surveys are $\sim 127$ to $285 \mathrm{~km}$ distant, and are located at similar depths (ZoNeCo-5: $2700 \mathrm{~m}$; ZoNeCo-12: 2500-2700 m), with presumably similar sedimentation regimes (Dickens et al., 2001).

Some oligotrophic sediments are problematic since their microbial community structure and geochemical characteristics overlap with those of hydrothermal sediments (Inagaki et al., 2001; Nercessian et al., 2005; Li et al., 2008) and the deep-water column. Several studies of oligotrophic abyssal sediments (Wang et al., 2004; Xu et al., 2005; Gillan and Danis, 2007) sampled only surficial sediments and recovered the same archaeal phylum, the Marine Group I Crenarchaeota, that is presumed dominant in the overlying water column (e.g., Karner et al., 2001; Church et al., 2003; Agogué et al., 2008; Durbin and Teske, 2010). Because of the high potential for cross-contamination and the phylogenetic similarity between oxic sediments and the overlying water column, to confidently label MG-I clones collected from oxic sediments as indigenous requires stringent contamination controls and/or investigations of the diversity of contamination sources (Durbin and Teske, 2010). Due to these difficulties, MG-I sequences were excluded from the current analysis.

\section{THE SEDIMENTARY TROPHIC STATE SPECTRUM}

In the following section, we summarize some of the most informative biogeochemical and microbiological parameters for 


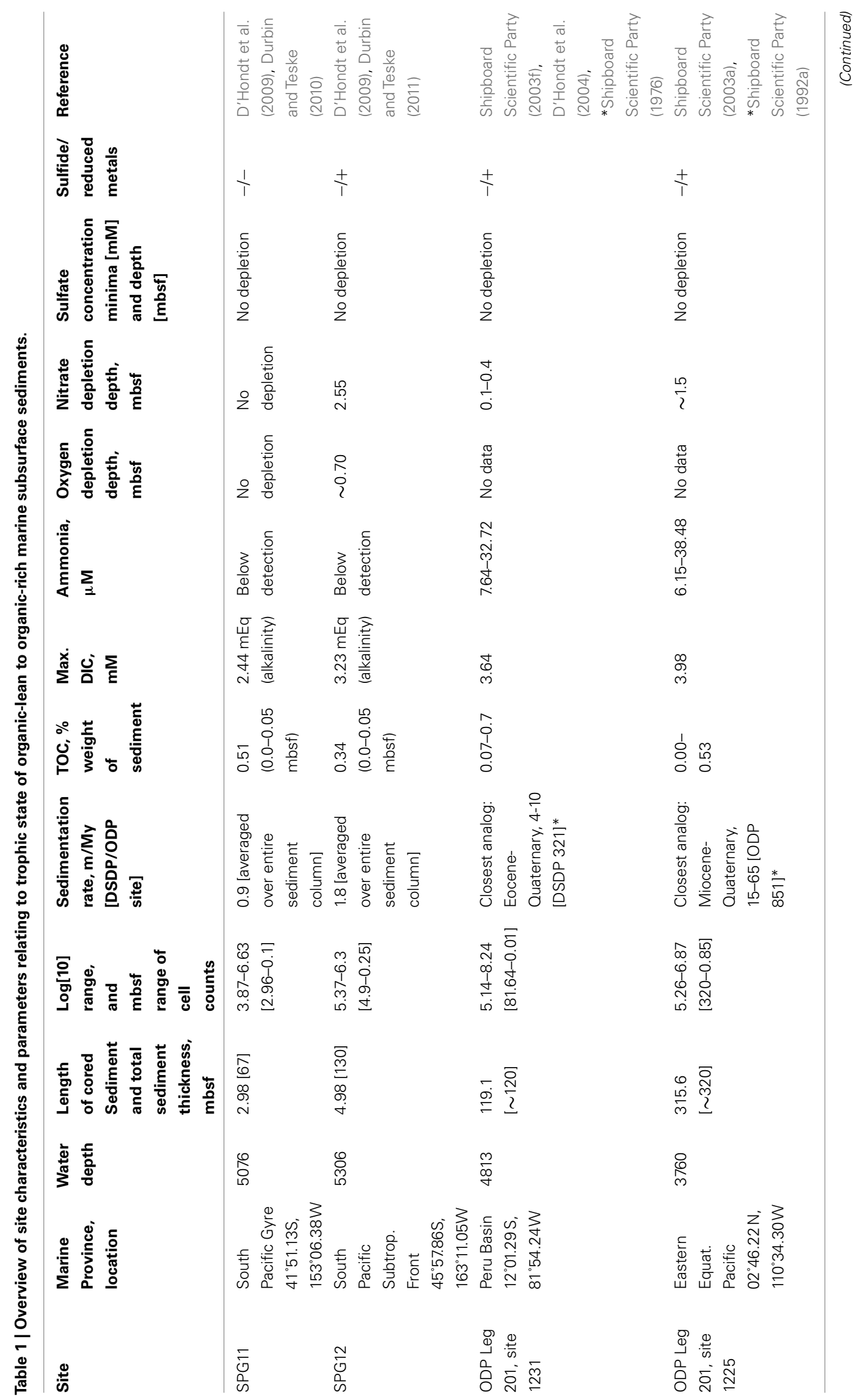




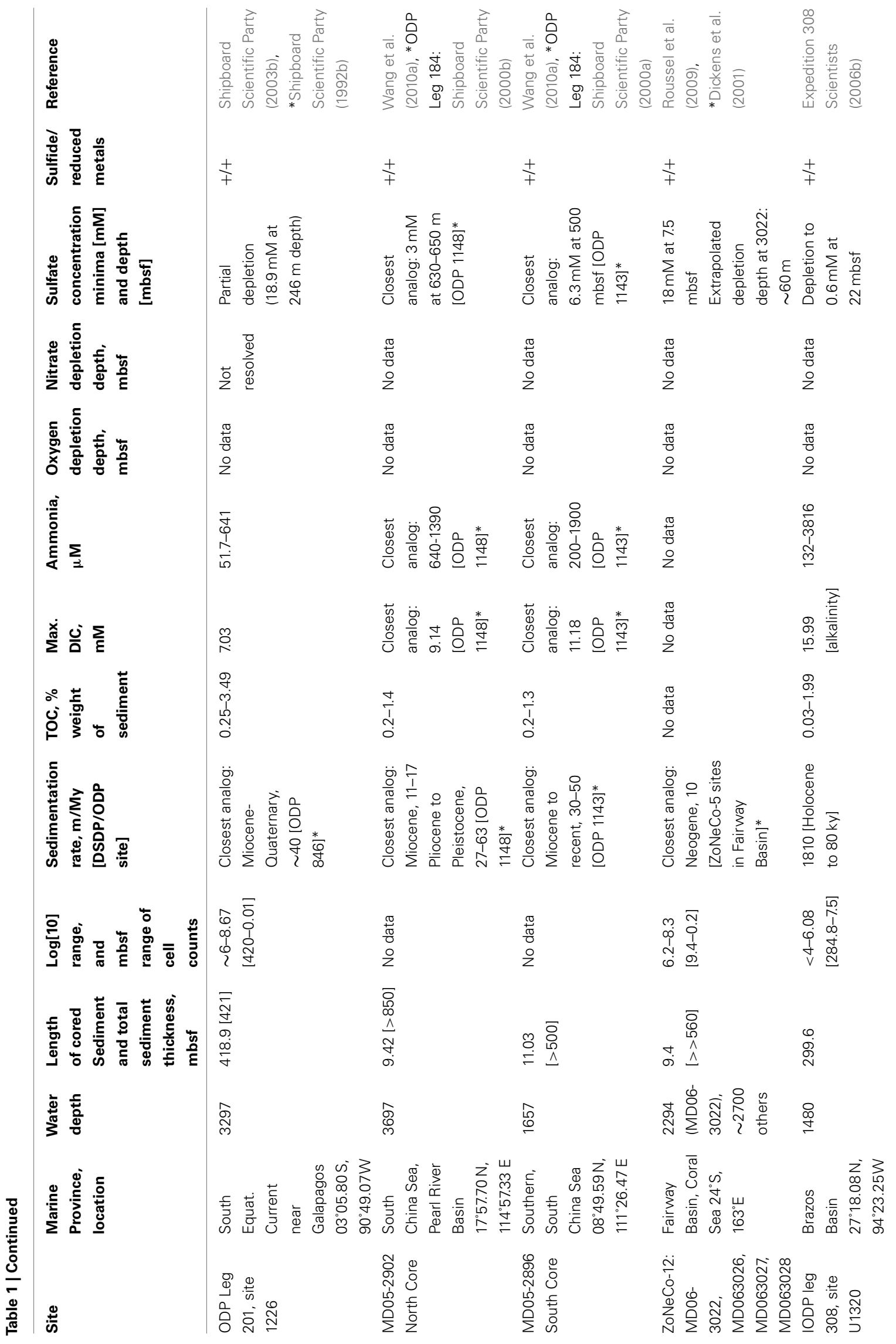



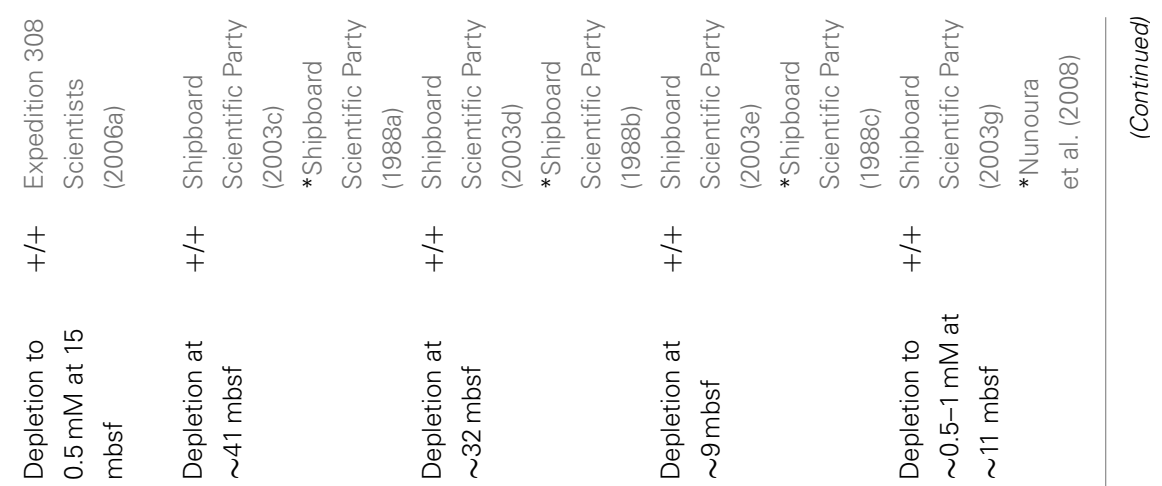

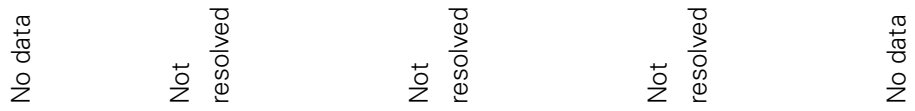

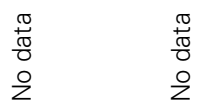

$\frac{\pi}{\pi}$
$\frac{\pi}{0}$
을

$\frac{\pi}{\pi}$
$\frac{\pi}{0}$
$\stackrel{0}{Z}$

$\frac{\pi}{\pi}$
$\frac{\pi}{0}$
$\stackrel{0}{Z}$

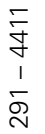

ป.

\begin{tabular}{lll}
$\infty$ & $\stackrel{1}{\infty}$ \\
\hdashline & $\infty$ \\
\hdashline & $\infty$
\end{tabular}

लि

$\stackrel{1}{\stackrel{0}{N}}$

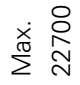

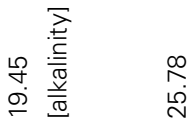

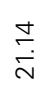

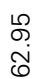

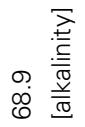

$\frac{9}{1}$

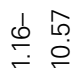

के
1े
ले
0
0

$\stackrel{\infty}{\infty}$

$\stackrel{1}{N}$
$\stackrel{1}{1}$
0
0
0

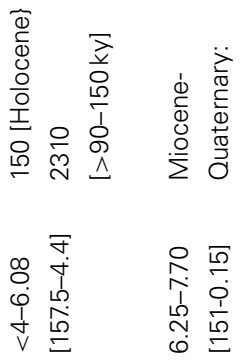

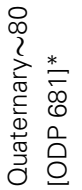

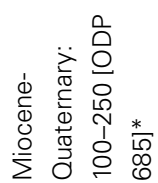

ำ

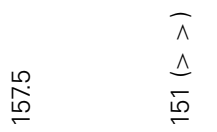

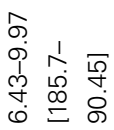

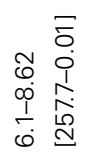

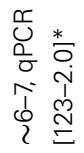

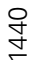

ฐ

$\widehat{\Lambda}$
$\stackrel{\Lambda}{\sigma}$
$\stackrel{\sim}{\sigma}$

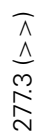

$\widehat{\lambda}$
$\hat{\Lambda}$
$\infty$
$\infty$
$\cdots$

巨్

@

怘

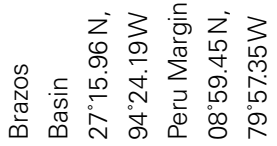

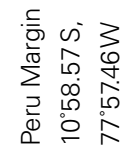

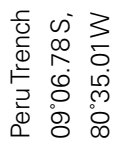

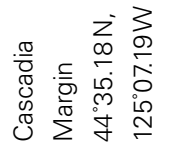

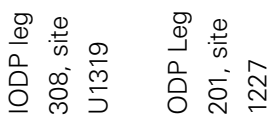

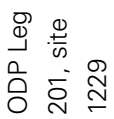

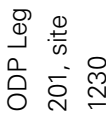

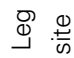

○ ठ 


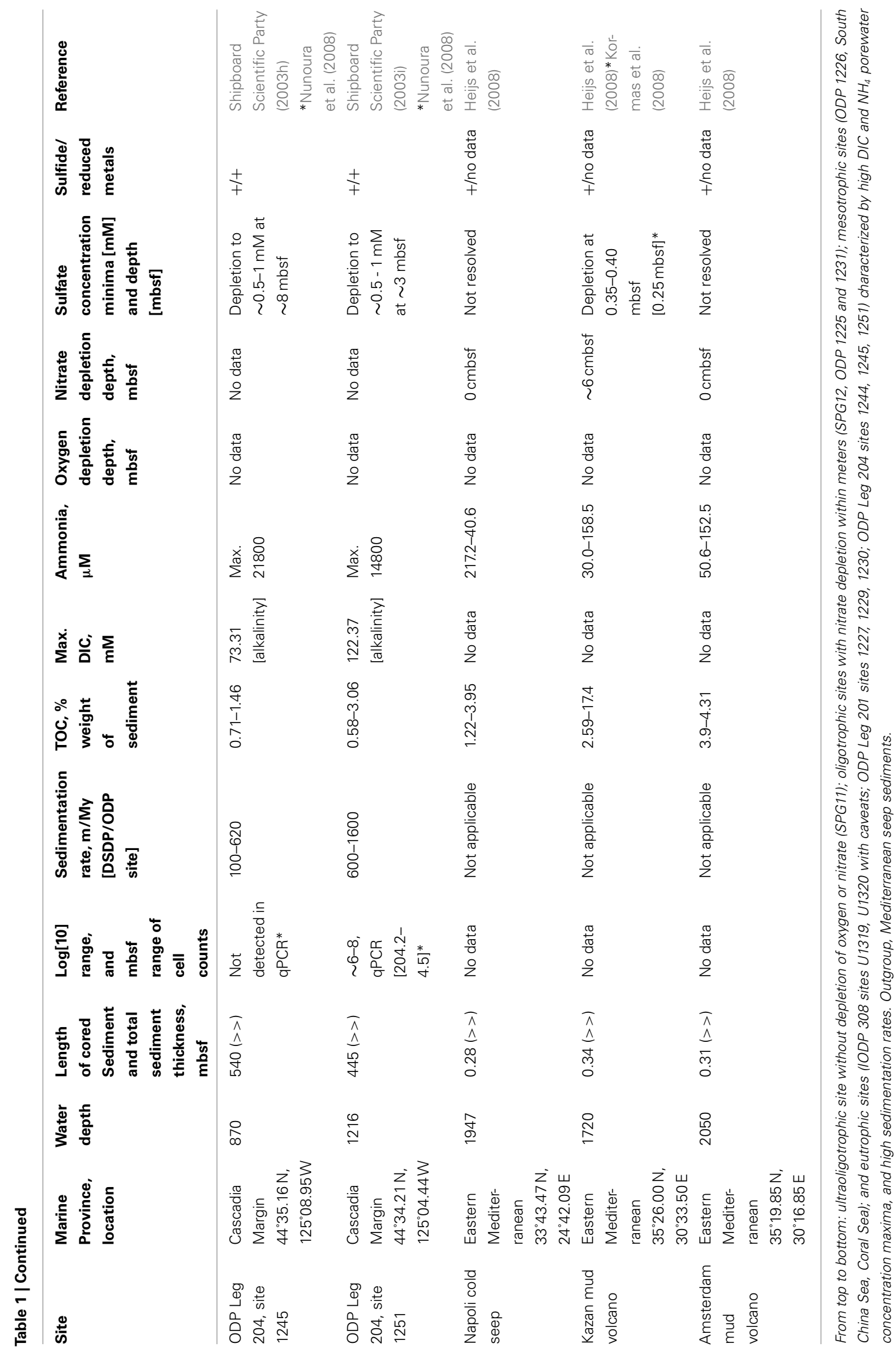




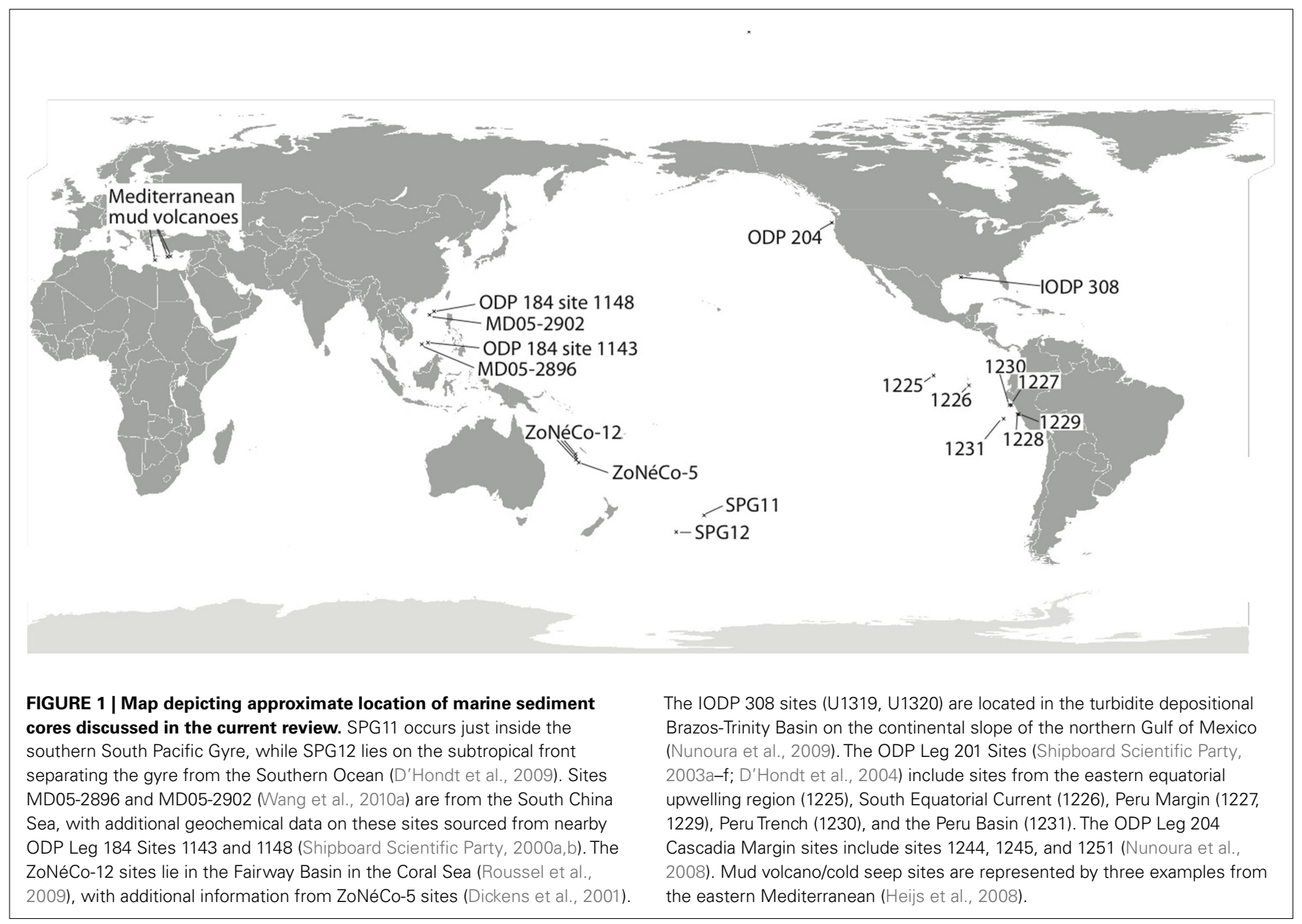

oligotrophic marine subsurface sediments (Table 1) and show that these sites appear to fall into several natural groups.

\section{SEDIMENTATION RATES}

Sedimentation rates can approximate sediment trophic states, albeit with some exceptions for high-carbonate or turbiditeassociated sedimentation and changing oceanographic conditions in the surface ocean, which can all enrich or impoverish deep marine sediments relative to the expected trophic state based on surface ocean productivity, or if a significant fraction of sedimentation is inorganic carbonate or silicate. Sedimentation rates at SPG Sites 11 and 12, are near 0.9 and $1.8 \mathrm{~m} / \mathrm{My}$, averaged over the entire depth and age of the sediment column (D'Hondt et al., 2009). For reference, averaged ocean sedimentation rates for the Atlantic, Pacific, and Indian Ocean based on DSDP cores ranged from 30 to $50 \mathrm{~m} / \mathrm{my}$ for quaternary sediments, and decreased to 2-5 m/my for paleocene sediments (Whitman and Davis, 1979). Among ODP Leg 201 sites, Site 1231 is the slowest-accumulating site, but still 4 to 10 times or 2 to 5 times faster than the South Pacific sites SPG11 or SPG12 (Table 1). The Peru Margin, Peru Trench, and Cascadia Margin sites form a cohort with increasingly high sedimentation rates, up to $1600 \mathrm{~m} / \mathrm{my}$ at Cascadia Margin site 1251 (Table 1), three orders of magnitude higher than at the South Pacific sites (Table 1), dramatically illustrating the different constraints shaping eutrophic margin environments and ultraoligotrophic gyre sediments. An extreme outlier are the Gulf of Mexico slope turbidite sediments sampled on IODP Expedition 308 (Table 1).

\section{POREWATER DIC}

Concentrations of porewater DIC above or below the mean seawater concentration are an indicator of the magnitude and direction of net metabolism. Net heterotrophy due to remineralization of organic matter to $\mathrm{CO}_{2}$ increases DIC concentrations, at least at the more oligotrophic end of the scale; in highly organic-rich sediments, a large fraction of organic carbon may be remineralized not to $\mathrm{CO}_{2}$ but to methane. Nevertheless, because DIC directly reflects metabolic rates, it integrates over unknowns inherent in interpreting sedimentation rates or electron acceptor depletion profiles. Comparisons of maximum DIC for Leg 201 sites suggest a spectrum from highly DIC-enriched Cascadia Margin sites 1244, 1245, and 1251 and Peru Trench Site 1230, to Peru Margin sites 1229 and 1227, the Gulf of Mexico Expedition 308 sites, the South China Sea sites, to ODP sites 1226, 1225, and 1231; the SPG sites 12 and 11 mark the DIC-poor end of the spectrum (Table 1). Here, alkalinity ( $\sim 96 \%$ of which is DIC, at seawater $\mathrm{pH})$ remains at seawater values throughout the sampled sediment column at SPG11, while SPG12 displays a downcore alkalinity increase concomitant with oxygen drawdown, and stabilizing thereafter (Table 1). Maximal porewater $\mathrm{NH}_{4}$ concentrations show the same trend and sort the 
sites into the same sequence as porewater DIC (Table 1), reflecting the origin of $\mathrm{NH}_{4}$ from remineralization of buried biomass.

\section{ORGANIC CARBON AVAILABILITY}

Organic carbon concentration is not a directly proportional measure of sediment trophic state, as substrate lability and organic carbon residence time can vary between sediments with similar organic carbon contents. Therefore, trophic state of the sediment can change without necessarily affecting the sediment organic carbon percent weight, and organic carbon content between sites of possibly different trophic state can overlap. Among the South Pacific Gyre sites, organic carbon content values for SPG11 ranged from 0.59 to 0.45 dry weight $\%$ over the upper $9 \mathrm{cmbsf}$ (centimeter below surface), with little change after the upper $2 \mathrm{cmbsf}$; surface sediments $(0-5 \mathrm{cmbsf})$ from SPG12 contained $0.34 \%$ (D'Hondt et al., 2009). A global TOC analysis in marine sediments showed that abyssal sediments contain less than or at most 1 weight $\%$ TOC, close to the global mean for marine sediments (Seiter et al., 2004); this is consistent with the oligotrophic sites in this survey. Higher TOC values in the range of up $1-2 \%$ are shared by the South China Sea sites and the Gulf of Mexico turbidite sediments (Table 1). The eutrophic Leg 201 sites varied between $\sim 1$ and 10\% TOC for different horizons, with $\sim 4 \%$ most typical for the majority of the sediment column, and typically decreasing with depth (Table 1). Interestingly, the Cascadia Margin Leg 204 sites showed lower TOC concentrations (maxima ca. 1.5-3\%) than the Leg 201 Peru Margin and Peru Trench sediments, and resembled in this regard the Gulf of Mexico turbidites (Table 1).

\section{CELL DENSITIES}

Total prokaryotic cell densities at the SPG sites are the lowest yet recorded for any equivalent depth horizon (D'Hondt et al., 2009). For all sites, cell counts declined with sediment depth, with the lowest value typically being the deepest. Cell counts ranged from $10^{3.9}$ to $10^{6.6}$ per $\mathrm{ml}$ over the upper $2.8 \mathrm{~m}$ at SPG11, and $10^{5.4}$ to $10^{6.3}$ per $\mathrm{ml}$ over the upper $\sim 5 \mathrm{~m}$ at SPG12, again setting SPG11 apart. These cell counts were lower than those of deepwater ODP sites 1231 and 1225 at comparable depth; the deepwater ODP sites had similar or higher cell counts over a much broader depth range, and declined to their lowest levels of $\sim 10^{5}$ at greater depths, $81.6 \mathrm{mbsf}$ for 1231 and $320 \mathrm{mbsf}$ for 1225. Given their location on continental margins, the Gulf of Mexico turbidite sediments of Expedition 308 had unusually low cell densities; the maxima in the range of $10^{5.3}$ to $10^{6.08}$ cells per $\mathrm{ml}$ were found near the sediment surface, and cell densities decreased rapidly with depth (Nunoura et al., 2009). Cell counts of the mesotrophic ODP 1226 and the eutrophic Peru Margin and Trench sites ranged from $10^{6}$ to $10^{10}$ cells per $\mathrm{cm}^{3}$ throughout the sediment column (Table 1). No direct cell counts are available from the ODP 204 sites; the qPCR data for $16 \mathrm{~S}$ rRNA gene copy numbers have to be viewed with caution, given occasionally complete PCR inhibition (Nunoura et al., 2008).

\section{OXYGEN, NITRATE, AND SULFATE GRADIENTS}

Typically, electron acceptors for microbial metabolism are depleted downcore in order of declining energy yield; depletion depth increases with organic substrate scarcity. Thus, organic-carbon limited sediments are expected to be deeply permeated by high-energy electron acceptors. Within increasingly organic-rich sediments, oxidants retreat toward the seawater/sediment interface, leading to a shrinking zone of oxidant availability. The porewater gradients of the strongest oxidants (oxygen, nitrate) are therefore strongly compressed toward the sediment surface, whereas the porewater profiles of weaker oxidants (oxidized metals, sulfate) extend deeply into the sediment column (D'Hondt et al., 2002, 2004).

At the ultraoligotrophic SPG11 site, oxygen drawdown is minimal and nitrate drawdown is not evident; porewater oxygen remains at $\sim 160 \mu \mathrm{M}$ at $280 \mathrm{cmbsf}$ and is unlikely to be depleted downcore, unless there are deep biotic or abiotic sediment oxygen sinks (D'Hondt et al., 2009). At site SPG12, oxygen becomes depleted near $70 \mathrm{cmbsf}$, and nitrate is depleted at $253-258 \mathrm{cmbsf}$ (D'Hondt et al., 2009). Oxygen data are not available for ODP sediment cores; sediment cores from ODP sites 1225 and 1231 show nitrate depletion on the scale of $10-40 \mathrm{cmbsf}$ for 1231, and $\sim 150 \mathrm{cmbsf}$ for site 1225 (Table 1). The surficial 1-2 m sediment horizons, and the nitrate and oxygen porewater profiles therein, are generally lost or disturbed during ODP coring. Nitrate and oxygen profiles in centimeter resolution can be obtained from sediment cores with undamaged surface layers, sampled by submersible or ROV. For example, downcore nitrate depletion occurred between 6 and $22 \mathrm{cmbsf}$ for the Kazan mud volcano, and indirect evidence points to oxygen penetration within the upper $6 \mathrm{~cm}$. Nitrate remained near 1-2 $\mu \mathrm{M}$ in the other two mud volcano sites (Amsterdam and Napoli), and no oxygen penetration could be inferred (Heijs et al., 2008).

Sulfate was not measurably drawn down at the SPG12 site, nor at the oligotrophic ODP sites 1231 and 1225. Mesotrophic ODP site 1226 displayed sulfate drawdown but not depletion over the entire sampled sediment column, along with apparent metal redox cycling to at least $\sim 70 \mathrm{mbsf}$ and methanogenesis throughout nearly the entire sediment column. Likewise, the ODP proxy sites from the South China Sea revealed sulfate drawdown but not depletion over several hundred meters of sediment. Sulfate profiles for the shallow Coral Sea cores are incomplete; however, extrapolating from the upper $9 \mathrm{~m}$ sulfate profile of Core MD063022 (Roussel et al., 2009) suggests a minimum depletion depth of $60 \mathrm{~m}$ or greater. The Gulf of Mexico and Peru Margin sites displayed sulfate depletion within tens of meters (D'Hondt et al., 2004), the Peru Trench and Cascadia Margin sites showed sulfate depletion within a few meters (Table 1). Often, porewater sulfate concentrations below depletion depth do not decrease to zero, but fluctuate in the range of 0.5 or $1 \mathrm{mM}$, reflecting sulfide reoxidation after exposure of sulfidic cores to oxygen. In Mediterranean mud volcano sediments, sulfate was depleted within the $\sim 40 \mathrm{~cm}$ measured for the Amsterdam and Napoli mud volcanoes, while the Kazan seep displayed little to no drawdown of sulfate (Heijs et al., 2008). Geochemical and microbial variability within each mud volcano site is evident from another recent survey of the Kazan mud volcano, where sulfate was drawn down within $25 \mathrm{~cm}$ sediment depth (Kormas et al., 2008).

\section{METAL REDOX CYCLING}

Metal reduction represents a key avenue for anaerobic terminal electron-accepting processes (Thamdrup, 2000). Manganese and iron reduction are both typical suboxic processes (Berner, 1981), with manganese reduction comparable to nitrate reduction, 
and reduction of amorphous iron oxyhydroxides closer to sulfate reduction in energy yield (Lovley and Goodwin, 1988). However, the fact that iron reduction involves both soluble and solid reactants and products, and the different bioavailability of different iron oxide phases, complicate iron geochemistry by introducing additional contingent factors. These include chemical surface inactivation (Fredrickson et al., 1998; Urrutia et al., 1998; Urrutia et al., 1999); retention of reduced iron in clay lattices, which counteracts product inhibition of iron reduction (König et al., 1997, 1999) and favors increased in situ free-energy yields for iron reduction; and the $\mathrm{pH}$ and phase dependence of free-energy yields (Postma and Jakobsen, 1996; Fredrickson et al., 1998), which may result in higher in situ energy yields for sulfate reduction. In particular, precipitation of the reduced byproducts of sulfate and iron reduction results in a mutualistic positive feedback that equalizes energy yields for both (Wang et al., 2008, 2010b). Together, these factors allow recalcitrant metal oxides to persist deep in anoxic zones (D'Hondt et al., 2004; Wang et al., 2008, 2010b), while Mn and reactive $\mathrm{Fe}(\mathrm{III})$ are mostly reduced nearer to the sedimentwater interface (König et al., 1997; Thamdrup, 2000; Wang et al., 2008).

Sediment redox state can be characterized by considering iron and sulfate reduction together. Ultraoligotrophic, oxic site SPG11 shows no evidence of either iron or sulfate reduction (Table 1). The anaerobic, oligotrophic sites SPG12, 1225, and 1231 display net iron reduction but no sulfide production. In mesotrophic and eutrophic sites from the South China Sea, Coral Sea, the Gulf of Mexico, the Peru Margin, Peru Trench, and Cascadia Margin, the precipitation of metal sulfides indicates co-occurring sulfate and iron reduction. Table 1 presents presence/absence patterns for sulfide and reduced metals for different sites, using both direct measurement of sulfide (Leg 201 and Mediterranean sites), dissolved porewater iron and manganese (Leg 201, Leg 204, and IODP 308 sediments), as well as indirect indicators for the presence or absence of reduced sulfur and metal species, such as a measured lack of net sulfate reduction (SPG12, SPG11), the presence of authigenic sulfide minerals (Leg 184, Leg 204), or brown-green color transitions (König et al., 1997; Thamdrup, 2000) that are an indicator of sedimentary $\mathrm{Fe}(\mathrm{III}) / \mathrm{Fe}$ (II) redox fronts (SPG12, Leg 184 sites, ZoNéCo sites, IODP308 sites).

\section{SEDIMENT TROPHIC STATE HIERARCHY}

In terms of electron acceptor gradients, oxygen and nitrate penetration over tens of centimeters to meters, and the absence of sulfate depletion, characterize the oligotrophic sites SPG12, ODP 1231, and ODP 1225; the lack of oxygen depletion at SPG11 sets this ultraoligotrophic site apart. Based on cell densities, nitrate and oxygen penetration depth, sedimentation rate, and possibly maximum DIC value, SPG12 is the most organic-lean among the oligotrophic sites, which would also include ODP deepwater sites 1231 and 1225. ODP Site 1226 and the South China Sea sites displayed sulfate drawdown but not depletion several hundred meters deep into the sediment, with the Coral Sea and the Fairway Basin also possibly in that category, suggesting a "mesotrophic" label for these sites. By contrast, eutrophic sites have oxygen and nitrate penetration depths of mere centimeters to millimeters, and sulfate depletion depths of tens of meters or less. The Gulf of
Mexico Expedition 308 sites show a curious mixture of eutrophic characteristics (high DIC and $\mathrm{NH}_{4}$ porewater concentration maxima, very high sedimentation rates) combined with mesotrophic (low TOC content) or even oligotrophic characteristics (very low cell numbers). The fully eutrophic sediments are represented by the Peru Margin, Peru Trench, and Cascadia Margin sites. Where available, DIC and $\mathrm{NH}_{4}$ porewater concentrations are perhaps the most reliable trophic state indicators, as they directly reflect the rate and amount of biomass recycled by microbial communities. Maximum DIC values range from seawater concentrations for ultraoligotrophic SPG11, to $>10 \mathrm{mM}$ for mesotrophic sites, and significantly more for eutrophic sites (Table 1). Maximum $\mathrm{NH}_{4}$ values range from below detection for the ultraoligotrophic SPG sites, to ca. $0.5-2 \mathrm{mM}$ for mesotrophic sites, and to $>3 \mathrm{mM}$ for eutrophic sites (Table 1).

\section{PHYLOGENY OF OLIGOTROPHIC ARCHAEA}

A key problem in surveying the archaeal diversity of marine sediments is reliably defining phylogenetically meaningful groups. Long branch attraction, hyperthermophile high-GC convergence (Boussau and Gouy, 2006; Brochier-Armanet et al., 2008), and chimeric sequences in public databases (Hugenholtz and Huber, 2003; Ashelford et al., 2005) result in statistically poorly supported clades - often para- or polyphyletic on closer inspection - that are highly dependent on details of species selection, and have little use in a phylogenetic context, but that are nevertheless reported in the literature. A related complication is the proliferation of different names for equivalent groups or nearly equivalent groups, which hampers comparability of results. As an attempt to address some of these difficulties, we constructed phylogenies of the major archaeal lineages (Figure 2), of the Euryarchaeota (Figures 3-5) and Crenarchaeota (Figure 6), which reflect the nomenclature introduced by a range of studies (Tables 2 and 3 ). Although these phylogenies do not address the deep relationships between archaeal phyla, such as the placement of Micrarchaeum and Parvarchaeum, and the grouping of Archaeoglobi, Methanomicrobia, and Halobacteria, these phylogenies are similar to well-supported clades reported in previous studies (e.g., Brochier-Armanet et al., 2008; Baker et al., 2010). Particular attention was given to the Thermoplasmata (Figure 5), in an effort to distinguish phylogenetically valid clades, alongside the organic-rich-associated MBG-D clade, that occur in oligotrophic sediments. The phylogenetic structure of the uncultured Thermoplasmata, and other highly diversified groups, such as the MCG archaea, remains a work in progress.

\section{ARCHAEAL OCCURRENCE TRENDS ACROSS SITES}

Relative abundances of deeply branching Archaeal lineages in 16S rRNA gene clone libraries from oligotrophic and organic-rich sediments are compiled in Figure 7. These 16S rRNA gene clone library data should not be understood as accurate proportional representation of archaeal lineages in the environment; diverging methodologies, clone library size limitations and the resulting detection thresholds qualify what is subsequently called "abundance." High-throughput sequencing approaches are very likely to modify these initial clone library-based surveys (Biddle et al., $2008,2011)$. Yet, the clone library data provide a window into distinctly different detection patterns of archaeal clades within 


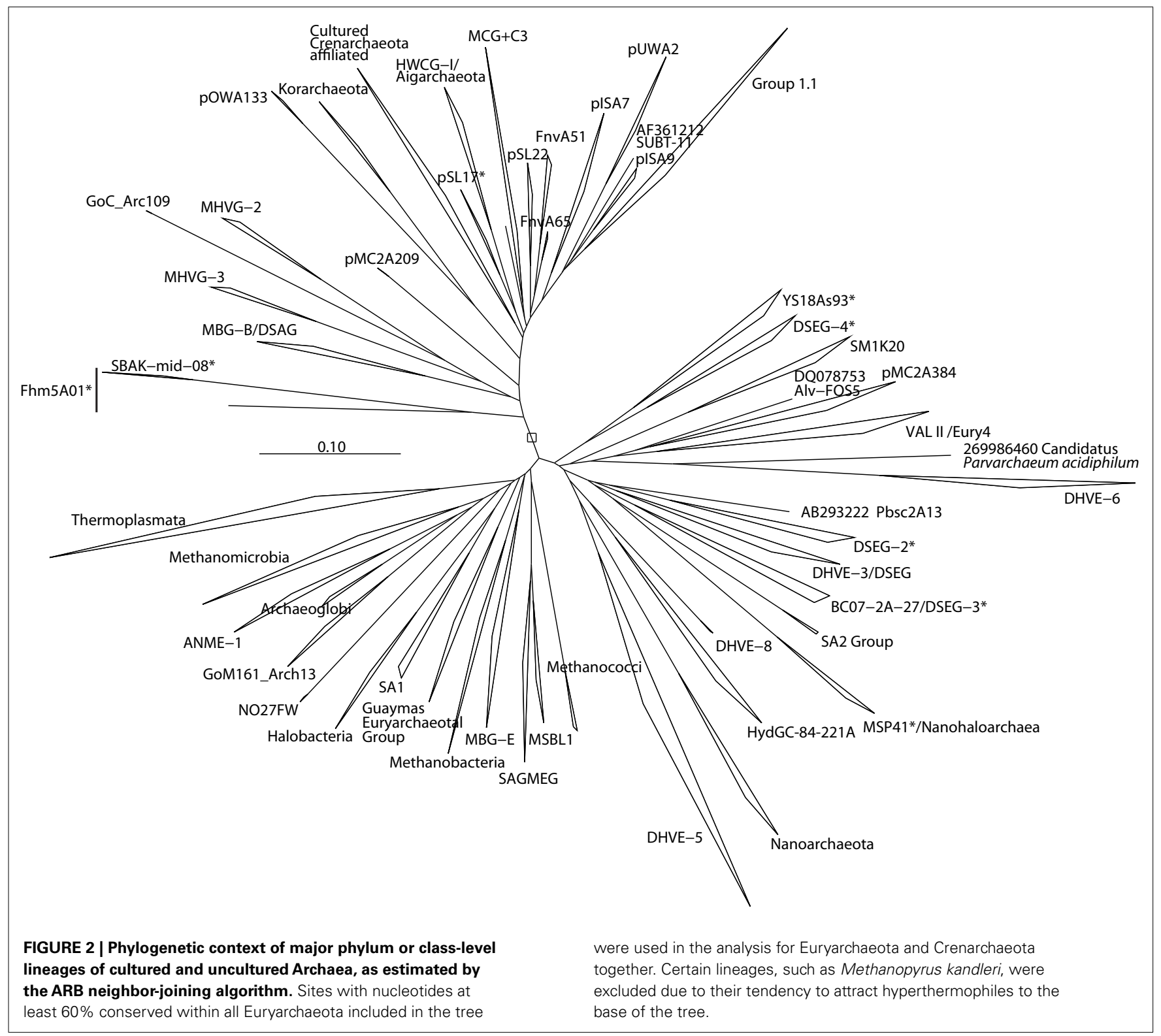

organic-lean and organic-rich sediments. All clades absent from eutrophic sites, or which occur at less than $1.5 \%$ relative abundance in any eutrophic site, are colored blue (numbers 1-16 in Figure 7). Those clades found only in the eutrophic end-member sites, or which occur in these sites at more than $1.5 \%$ frequency, are colored red. Overall, archaeal phyla that predominate either in the oligotrophic or in the eutrophic endmember sites are declining in relative abundance along environmental gradients of redox state, organic carbon content and biomass remineralization (Figure 7; Table 1). Dominant benthic archaeal groups of organic-rich sediments disappear in the most oxidized sediment environments, and vice versa.

A specific archaeal assemblage of MBG-B, MCG, SAGMEG and MBG-D archaea is found repeatedly in the eutrophic subsurface sediments of the Peru Margin (ODP sites 1227,1229), Peru Trench (ODP site 1230), Cascadia Margin (ODP sites 1244,
$1245,1251)$, and the highly reducing Mediterranean methane seeps, and also in the Gulf of Mexico 308 sites with mixed eutrophic/mesotrophic/oligotrophic characteristics. These uncultured archaeal lineages that are commonly detected in clone libraries (Table 2) should be congruent with the cren- and euryarcheotal proportion (15-45\%) of phylogenetically informative pyrosequencing fragments in the Peru Margin and Brazos Basin metagenomes (Biddle et al., 2008, 2011). The archaeal groups that are typically found in eutrophic sediments also persist to a considerable extent into organic-leaner sediments. For example, MCG is found in all mesotrophic sites in the South China Sea, Fairway Basin, and ODP site 1226; MBG-B persists in the same sites in the mesotrophic spectrum, and also in ODP sites 1225 and 1231 (Figure 7). Some members of these and other archaeal clades that are typically found in anaerobic, eutrophic marine sediments also occur in reducing, non-marine habitats. For example, the MCG 


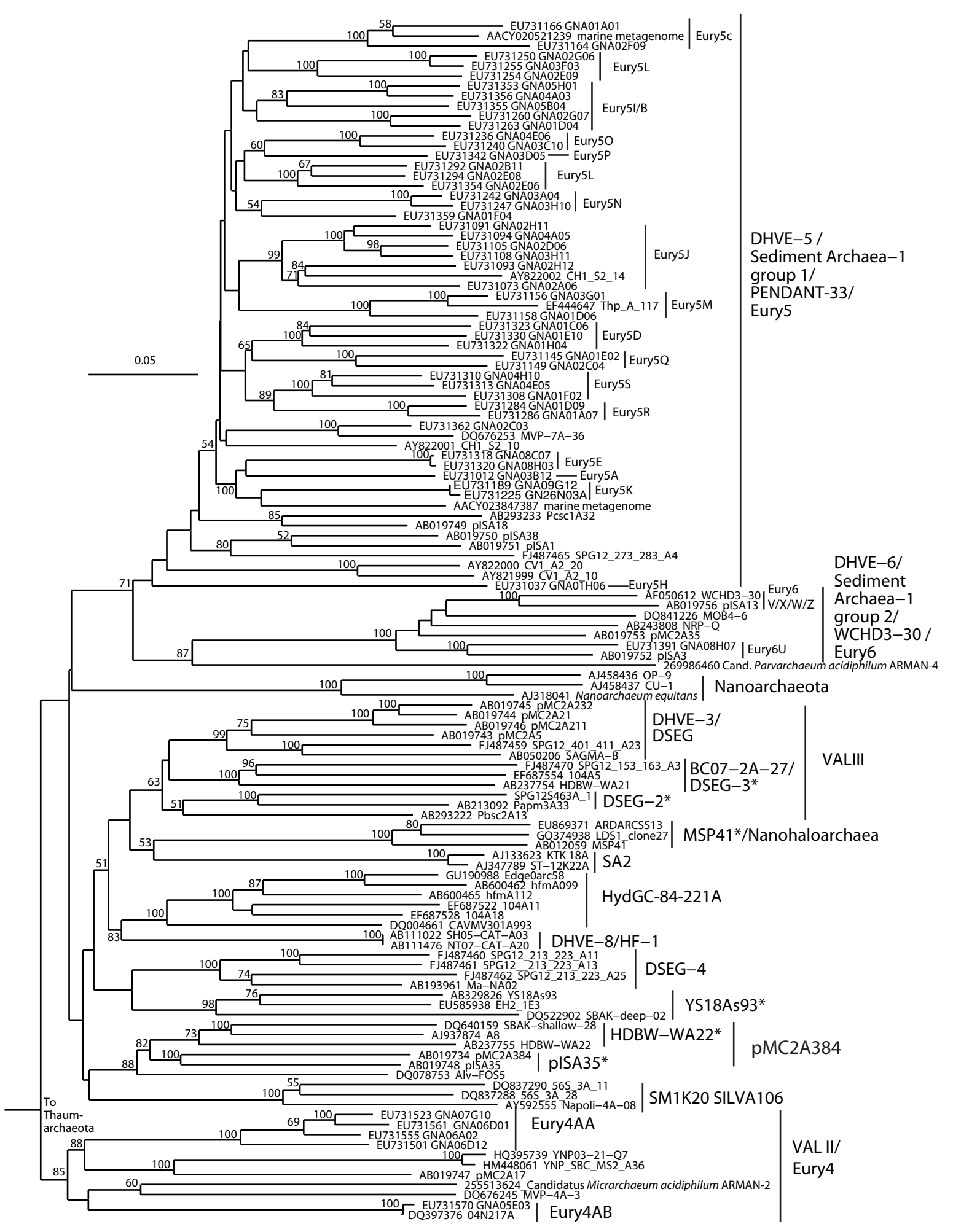

FIGURE 3 | Neighbor-joining 16S rRNA gene phylogeny of apparently deeply branching Euryarchaeota, designated DHVEG-II after Takai and

Horikoshi (1999). Alignment size, filtered using the arch_ssuref mask available in ARB, is 1090 sites. Statistical support was estimated using 500 maximum likelihood bootstrap replications in TreeFinder (Jobb et al., 2004). Branches are annotated with names and acronyms that are used in the literature (Table 3).

The archaeal taxa marked with asterisks are novel designations introduced either in Durbin and Teske, 2011 or in this study (Table 3). 


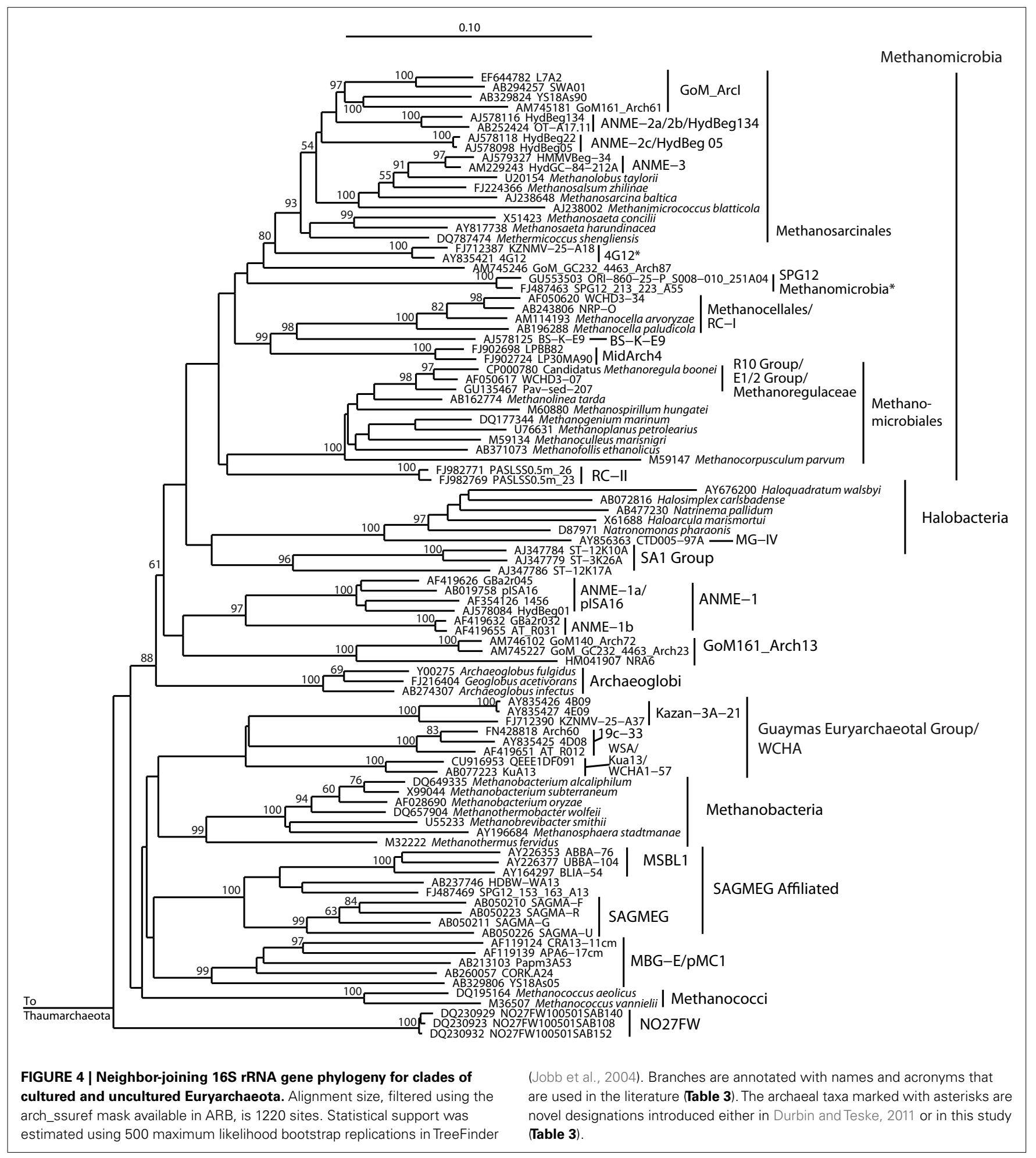

occurred in the anaerobic digestor and in several marine samples; the Guaymas Euryarchaeotal Group (Dhillon et al., 2005) was also found in the anaerobic digestor (Chouari et al., 2005) and in the Mediterranean methane seeps (Heijs et al., 2008); and methanogens were recovered in the rumen library and among the Peru Margin/Trench sequences.
The oligotrophic end of the sediment spectrum starts with an entirely different archaeal community. The most oligotrophic site featured in Table 1 is SPG11, where oxygen is present throughout the measured sediment column and DIC (alkalinity) does not vary from seawater values (D'Hondt et al., 2009). All archaeal sequences recovered for this site were members of MG-I, and formed 


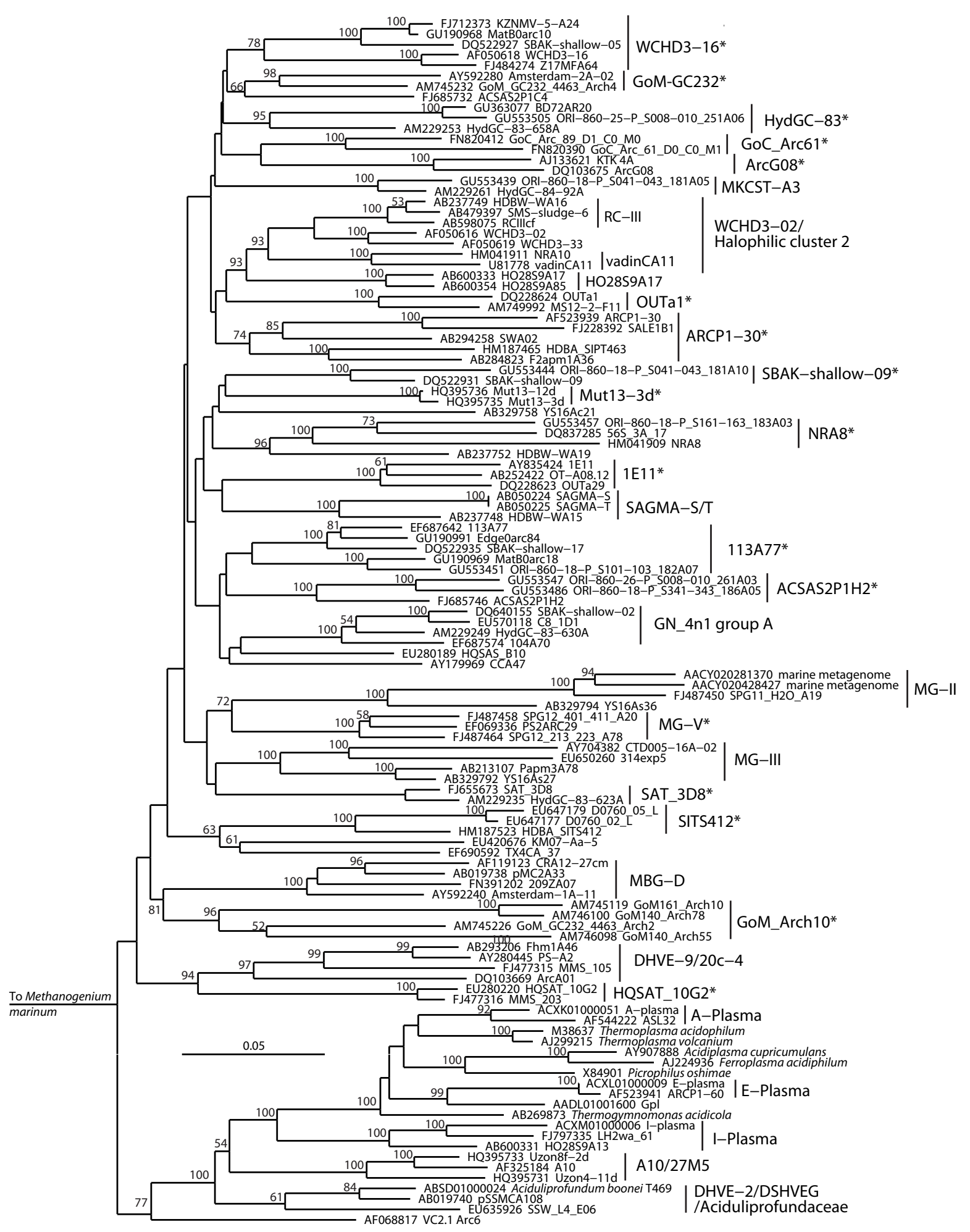

FIGURE 5 | Neighbor-joining 16S rRNA gene phylogeny of Thermoplasmata-affiliated monophyletic lineages in the Euryarchaeota.

Alignment size, filtered using the arch_ssuref mask available in ARB, is 1145 sites. Statistical support was estimated using 500 maximum likelihood bootstrap replications in TreeFinder (Jobb et al., 2004). Branches are annotated with names and acronyms that are used in the literature (Table 3). The archaeal taxa marked with asterisks are novel designations introduced either in Durbin and Teske, 2011 or in this study (Table 3). 


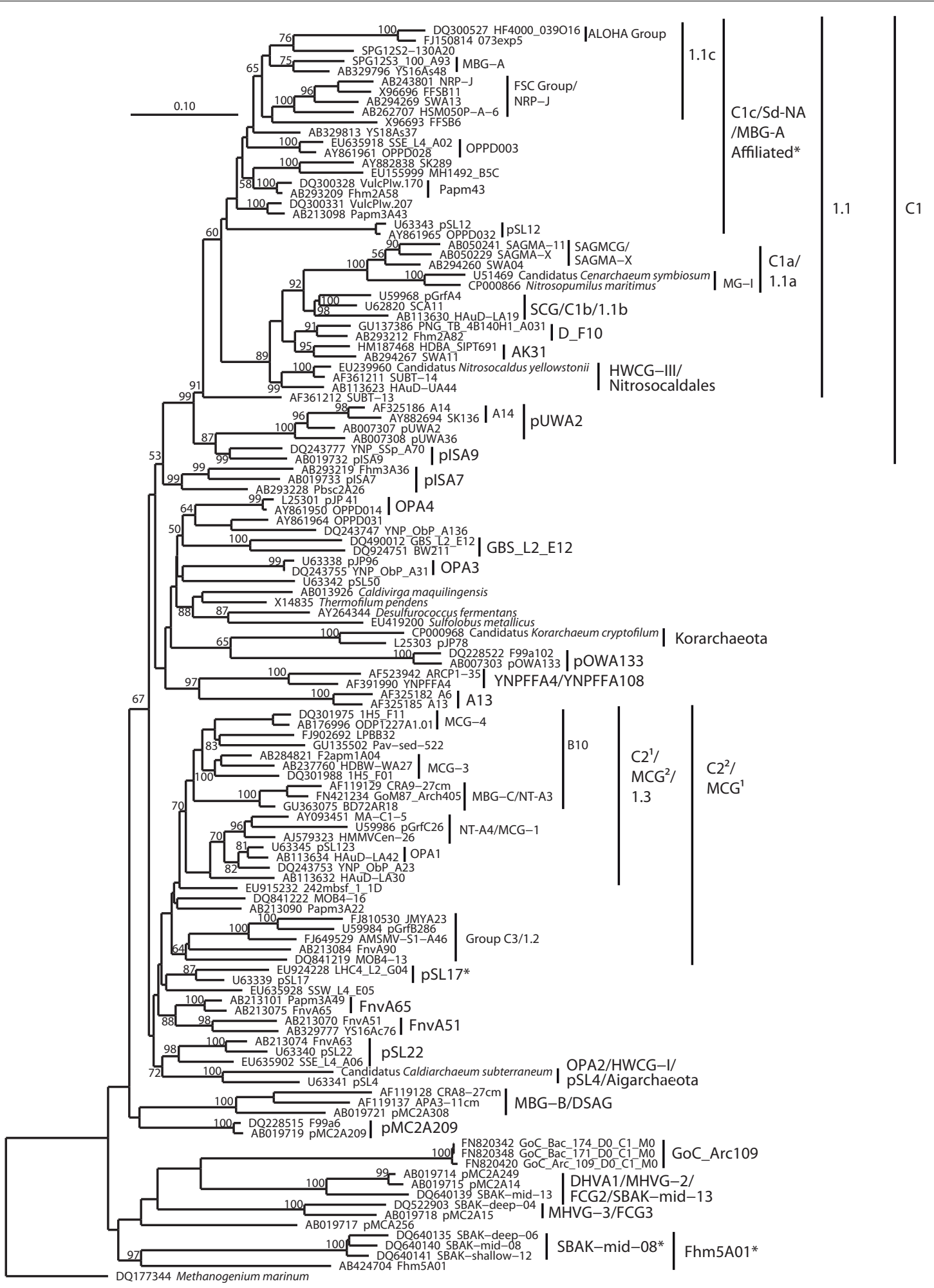

FIGURE 6 | Neighbor-joining 16S rRNA gene phylogeny of Crenarchaeota/Thaumarchaeota and associated deeply branching lineages. Alignment size, filtered using the arch_ssuref mask available in ARB, is 1177 sites. Bootstrap support was estimated using 500 maximum likelihood bootstrap replications in TreeFinder (Jobb et al.,
2004). Branches are annotated with names and acronyms that are used in the literature (Table 3). The archaeal taxa marked with asterisks are novel designations introduced either in Durbin and Teske, 2011 or in this study (Table 3). Note that further MBG-B groups are defined in Robertson et al. (2009). 
Table 2 | Relevant methodological features for the archaeal clone library studies compared in this review.

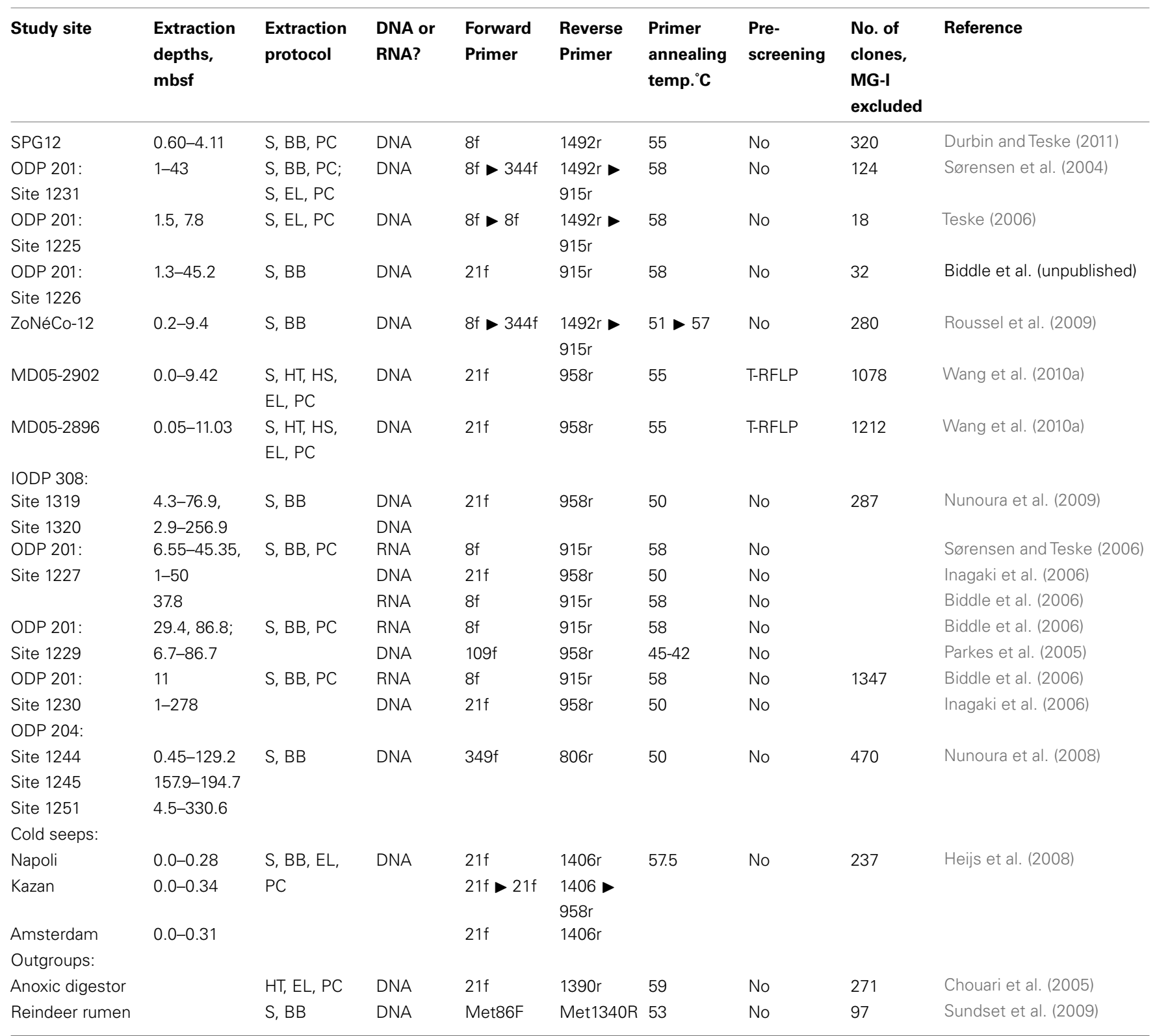

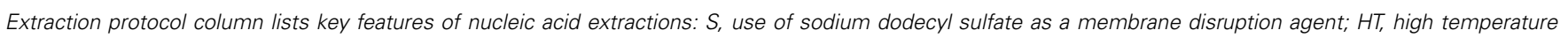

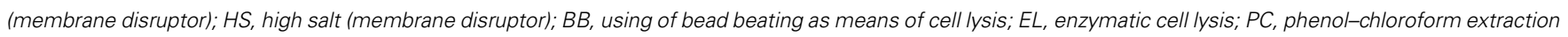

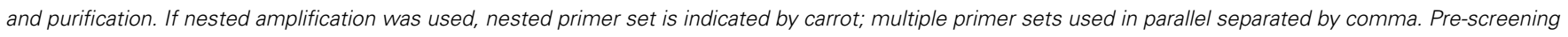

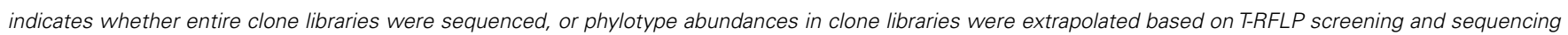

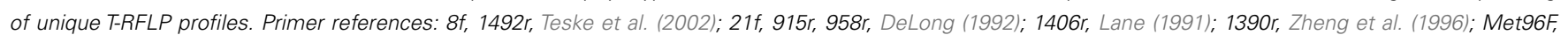
Met1340R, Wright and Pimm (2003); 344f, Sørensen et al. (2004); 109f, Großkopf et al. (1998a); 349f, Takai and Horikoshi (2000).

sediment-specific clades within this lineage (Durbin and Teske, 2010). However, MG-I archaea also appear occasionally in very deep sediment samples (such as ODP1230; Inagaki et al., 2006) where they almost certainly represent seawater or drilling fluid contamination; for this reason, MG-I archaea are not included in Figure 7. The oligotrophic site SPG12 resembles SPG11 in the dominance of MG-1 archaea (subsurface clusters) in the upper sediment layers and lacks the typical archaea of eutrophic sites (MCG, MBG-B, MBG-D); only a single SAGMEG-related clone and two divergent Methanogen-affiliated clones were recovered from SPG12. The dominant archaea at SPG12, including MG-V, DSEG-2, DSEG-4, and the MBG-A-related lineages, were not recovered from any of the organic-rich sediments (Figure 7). ODP sites 1225 and 1231 resemble SPG12 geochemically and microbiologically. Their clone libraries include a significant proportion of groups found in organic-lean sites (DSEG-4, MBGA), but also include some groups abundant at eutrophic sites (MBG-B). 


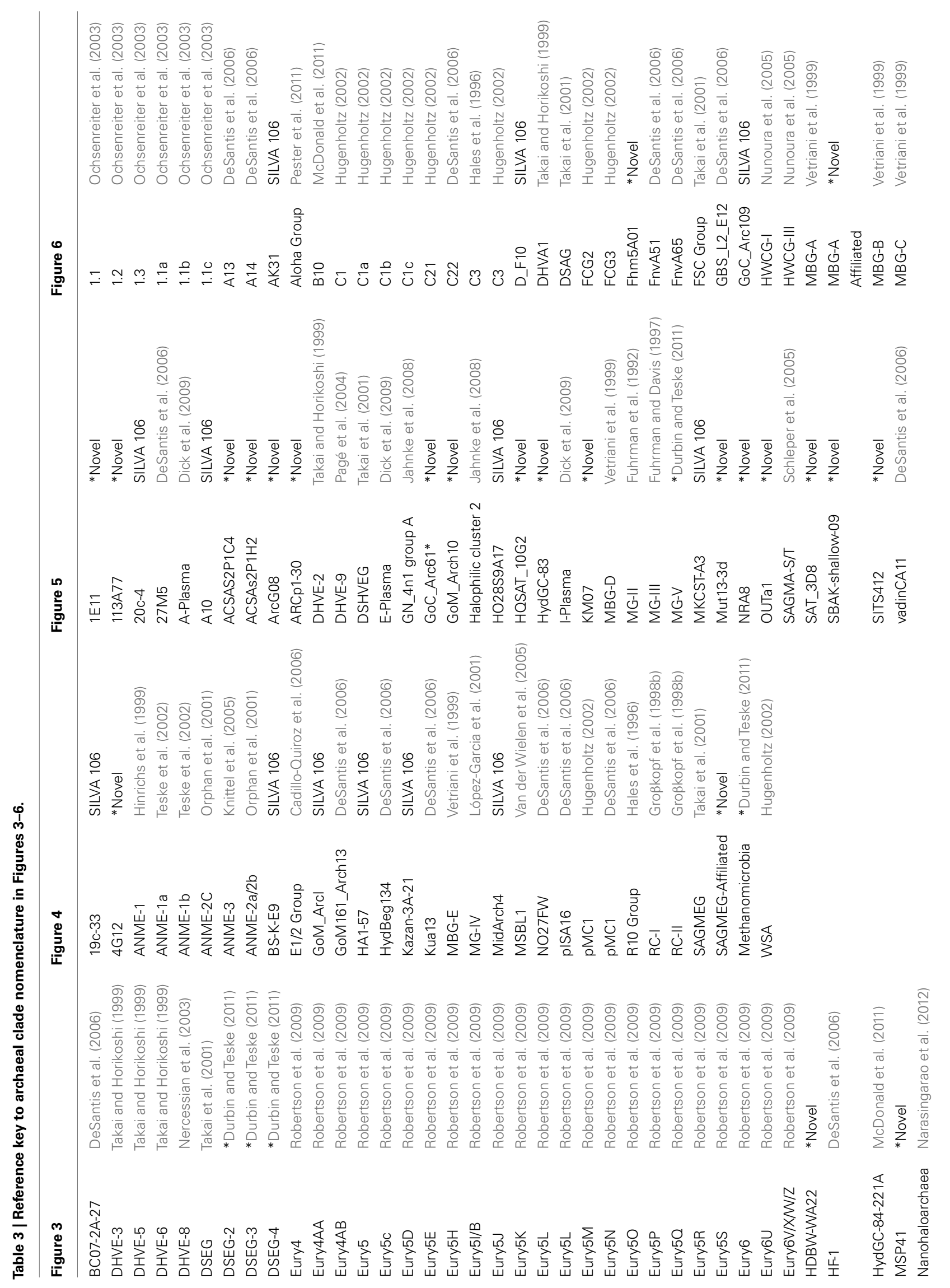




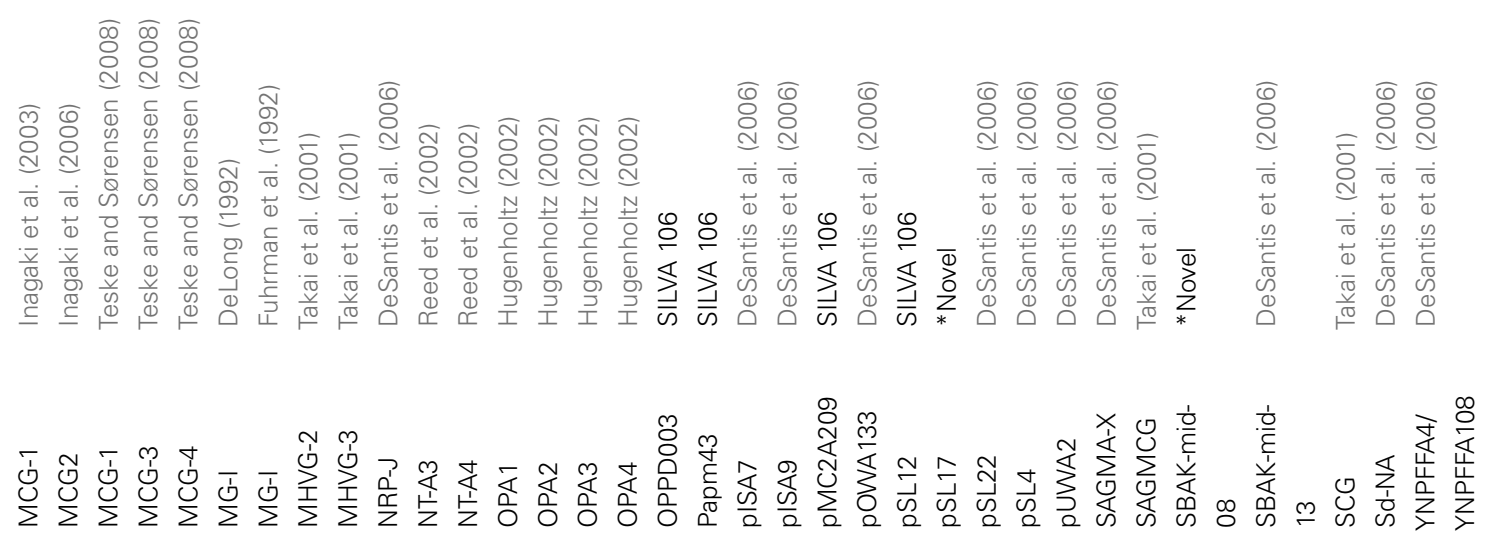

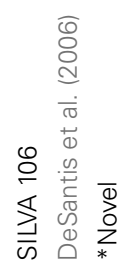

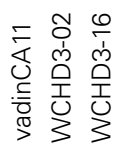
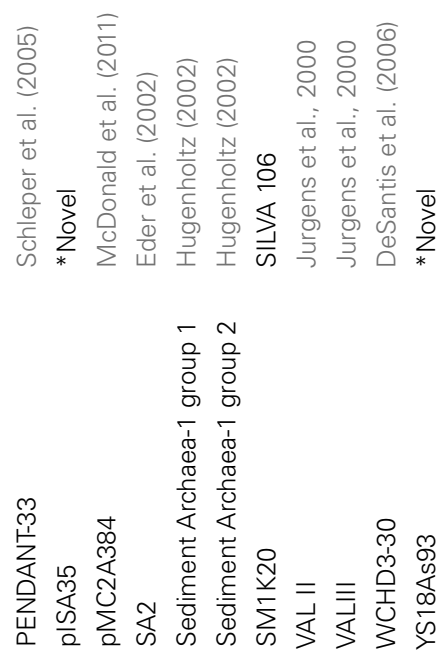


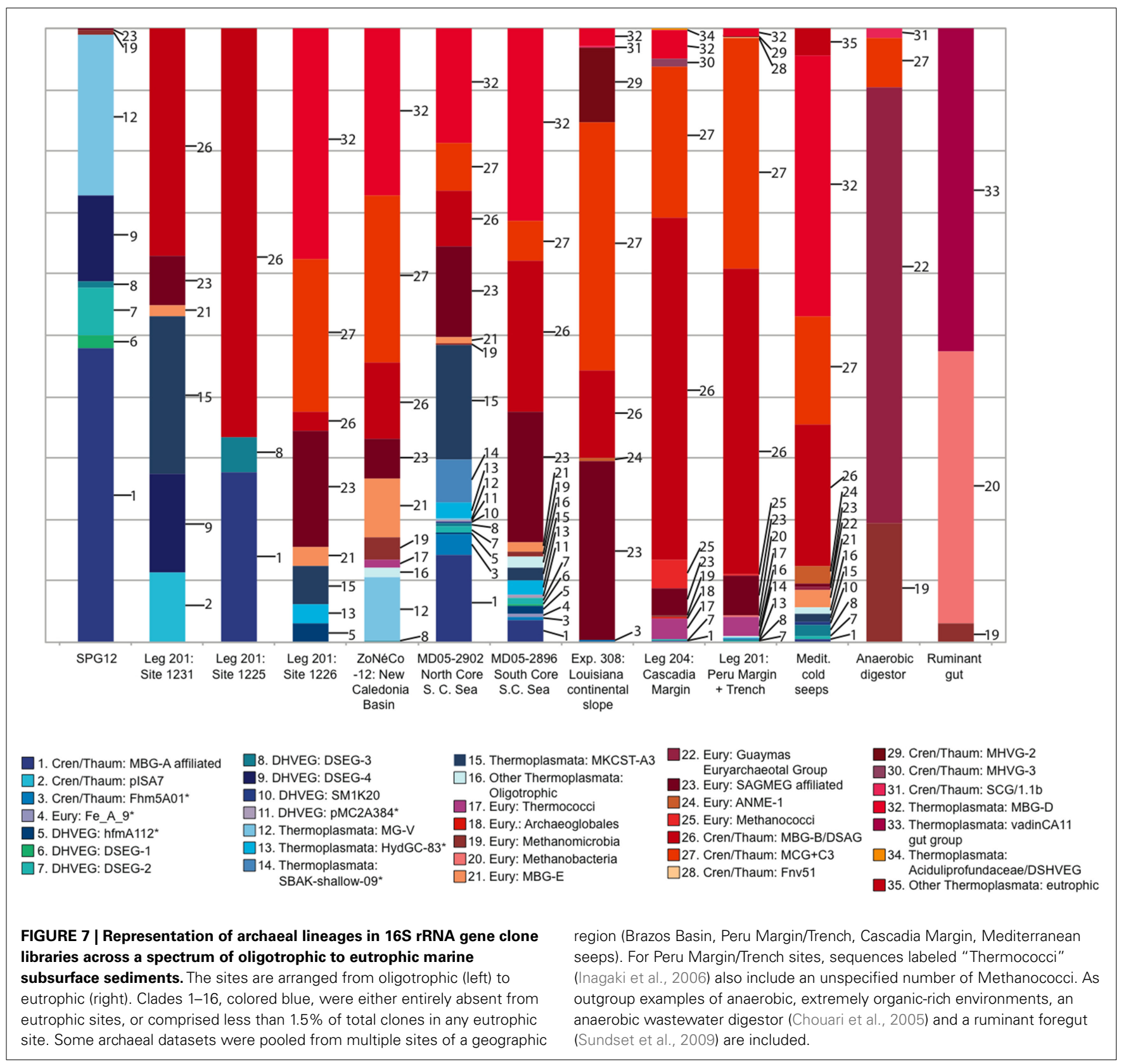

The intermediate, mesophilic spectrum includes ODP site 1226, and the South China and Coral Sea sites. In comparison to oligotrophic sites, these sites yielded a smaller proportion of lineages typical for organic-lean sites, congruent with more organic-rich habitat characteristics. As a caveat, the South China and Coral Sea cores are relatively shallow; deeper coring and sampling in these locations might impact the archaeal diversity results. The impact of shallow sampling can be seen in the detection of organic-lean archaeal lineages in the Mediterranean cold seep dataset, attributable to the shallow horizons sampled as well as the geochemically heterogeneous nature of cold seeps that are surrounded by organic-lean deep-sea sediments (Figure 7).

Despite these complications, the proportion of lineages common in organic-lean sediments decreases as measures of sediment

organic richness increase. Certain archaeal clades occur - in changing configuration - in oligotrophic sediments, but do not occur or occur only rarely in eutrophic sediments. There are three likely drivers of such a changes in community composition:

(1) Refractory organic matter. Organic matter changes significantly in composition and quantity during sinking, and is expected to become more refractory overall after passage through the deep-sea water column (Wakeham et al., 1997). Microbes that can metabolize the highly refractory substrates in oligotrophic sediments where competition for electron donors is strong would have an advantage over microbes not able to use these substrates. 
(2) Low sedimentation rates. Oligotrophic sediments are primarily characterized by slow sedimentation rates, leading to a low substrate flux for microbes and hence energy limitation. As the incoming carbon substrates are microbially degraded, increasingly recalcitrant compounds become enriched.

(3) Deep permeation of high-energy electron acceptors. Since decreasing sedimentation and carbon flux leads to slower depletion of electron acceptors, energy-rich electron acceptors (oxygen, nitrate) permeate a larger depth range of the sediment column in oligotrophic sediments, in contrast to the surficial sediments to which they are confined otherwise. Thus, some subsurface Archaea may specialize in the electron acceptor that maximizes the energy yield for a given substrate, and this leads to the predominance of specific archaeal lineages in oligotrophic sediments.

These variables are expected to be congruent to some degree. It also seems likely that some combination of these three factors determines community composition: while electron acceptor specialization may be a determinative factor for one group, another group may thrive since it uses a particularly recalcitrant carbon substrate.

This discussion of low-energy adaptations of microbial cells in oxidized, oligotrophic sediments should not distract from the fact that low-energy adaptations should also apply to microorganisms in organic-rich subsurface sediments where the lack of highenergy electron acceptors and of fresh carbon substrates impose very low free-energy fluxes at or near maintenance-energy requirements (Lever et al., 2010), such that microbial activity persists in sediment horizons over geological time scales (Parkes et al., 2005) and sustains very slow biomass turnover on time frames ranging from years to millennia (Jørgensen, 2011). The different archaeal communities in oligotrophic and eutrophic sediments should not be viewed in terms of simplistic "low-energy vs. high energy" habitat characteristics; instead, the distinct reduction potentials, substrate spectra, electron donors, and acceptors in oligotrophic and eutrophic sediment environments determine which catabolic, carbon-fixing, and biosynthetic pathways are feasible (McCollom and Amend, 2005).

\section{ASSOCIATION OF ARCHAEAL LINEAGES WITH HIGH-ENERGY ELECTRON ACCEPTORS}

The link between redox specialization and specific benthic archaeal lineages is not limited to sedimentary habitats: archaeal clades typical for oligotrophic sediments appear frequently in other oxic or suboxic environments, and less often in anoxic environments. In other words, mutually independent clone library surveys demonstrate that a given archaeal lineage is preferentially found in a particular redox environment. Figure 8 shows the number of different studies that have recovered a given lineage from a particular redox

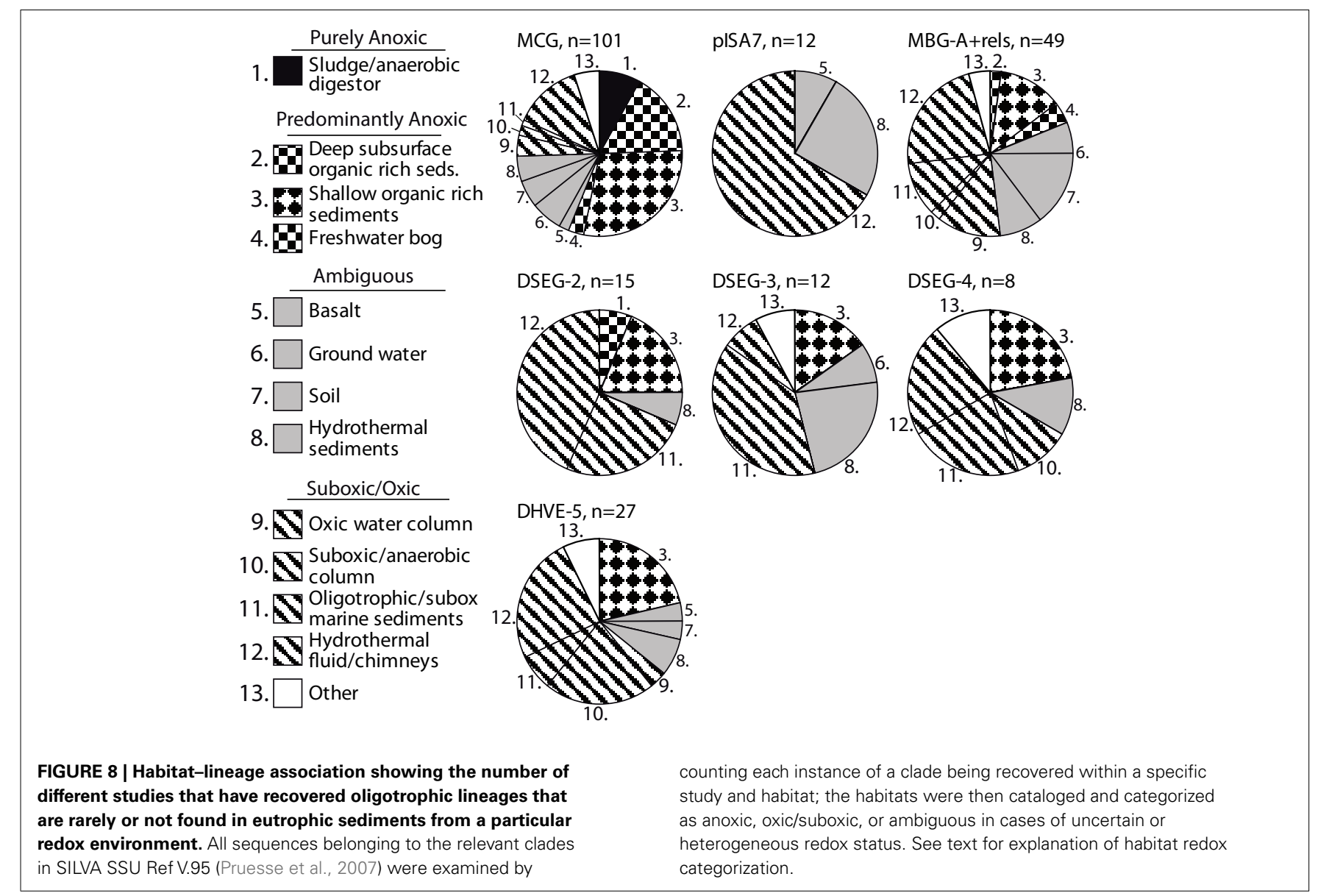


environment, for all relevant sequences in the SILVA SSU Ref v.95 database (Pruesse et al., 2007). Based on geochemical metadata for each sequence data set, the redox status of the environments considered was conservatively identified as purely anoxic, predominantly anoxic, ambiguous, and suboxic/oxic (Figure 8). Methodological biases inherent in DNA extraction method, PCR primer selection and cloning methodology rule out a strict proportionality of geochemical regime to clone library membership and relative abundance (Teske and Sørensen, 2008). Therefore, these cumulative presence/absence data can be thought of as "averaging" of experimental variability associated with PCR surveys of microbial diversity.

Notably, lineages from oxidized, organic-lean sediments have not been recovered from purely anoxic environments such as anaerobic digestors, indicating basic physiological incompatibility (Figure 8). However, some predominantly anoxic sites, mostly shallow organic-rich sediments, harbor lineages that are commonly found in oxidized sediments (Figure 8). These organic-rich sediment environments can be distinguished from the purely anoxic environments (such as anoxic bioreactors) because they often have oxidized niches or micro-environments that co-occur with anoxic niches (e.g., Jørgensen, 1977; Mäkelä and Tuominen, 2003; Jørgensen et al., 2005; Glud, 2008), particularly for near-shore marine sediments where weathering mineral input may introduce significant quantities of metal oxides (Poulton and Raiswell, 2002). These permeable boundaries between sediment habitat types might also work the other way around. For example, a key component of organic-rich, reduced marine subsurface sediments, the MCG archaea, also occur in freshwater bogs and in surficial, partially oxidized sediments (Kubo et al., 2012).

Hydrothermal fluids are often highly reduced and anoxic at their source, but turn more oxidized within the thermally habitable mixing gradient between an anoxic, hydrothermal source fluid, and an oxic endmember such as seawater, oxygenated groundwater, or atmosphere-exposed surface water (e.g., Amend and Shock, 1998; Teske et al., 2002; Spear et al., 2005; Dias and Barriga, 2006; Rogers and Amend, 2006). As a consequence of hydrothermal convection and seawater admixture, archaeal lineages that are associated with oxidized, organic-lean sediments could thrive in the shallow, partially mixed and partially oxidized vent subsurface, and are then frequently recovered from hydrothermal fluids (Figure 8). The second largest group of source habitats for these archaeal lineages that tolerate partially oxidized conditions are environments with heterogeneous or variable redox states, such as soil (Conrad, 1996), ground water (Jakobsen, 2007), and surficial hydrothermally influenced sediments and mineral deposits permeated by hydrothermal fluid (Teske et al., 2002; Nercessian et al., 2005; Dias and Barriga, 2006; Severmann et al., 2006). These habitats provide access to high-energy electron acceptor niches.

Thus, partially oxidized environments, including oxic/suboxic sediments or water column, and the redox-oscillating environments of hydrothermal fluids and chimney surfaces, account for a majority or plurality of detection of organic-lean archaeal lineages, such as the pISA7 Crenarchaeotal and the DHVEG-II Euryarchaeotal lineages (Figure 8). As a caveat, these trends are suggestive but require consistency checks over increasingly finegrained phylogenetic scales; minority clades within lineages may have metabolisms that are atypical for that lineage. The observed patterns also reflect uncertainty in identifying the exact redox state of the environment from which the clone was recovered, particularly problematic for datasets with sketchy or unspecific sequence-source descriptions. With these limitations, these results are again compatible with a metabolism requiring high-energy electron acceptors and oxidized redox conditions for the archaeal lineages from organic-lean habitats.

\section{PROBLEMS AND PROSPECTS FOR FUTURE RESEARCH}

Considerable uncertainty remains regarding the phylogeographic trends described and their putative link to environmental redox state. Principally, these uncertainties revolve around the familiar problems of primer and PCR bias, the significant variation in availability of key geochemical measurements, and the meager database especially at the oligotrophic end of the spectrum. Improving the cross-comparability of $16 \mathrm{~S}$ rRNA survey data would require consistent molecular methodology as well as unified geochemical metadata across a wide range of marine sediment environments; this problem is acute in large-scale molecular surveys of the marine microbial world (Zinger et al., 2011). New sampling sites with good metadata, for example the oligotrophic sediments of North Pond underlying the North Atlantic subtropical gyre, are being explored (Ziebis et al., 2012) and will enlarge the molecular database as well. Additional evidence from cultivations, genome sequencing, and environmental genomics, is needed to further query the functional repertoire of archaeal 16S rRNA lineages. For example, genome analysis, enrichments, and cultivations of Thaumarchaeota (MGI archaea) suggest an ammonia-oxidizing metabolism for this archaeal lineage (Pester et al., 2011), a conclusion at least partially consistent with the largely suboxic/microoxic habitat preferences of the MG-I-related lineages discussed here.

Detailed environmental 16S rRNA surveys and geochemical measurements are complementary to genomic and cultivation approaches, given that neither genomics nor cultivations currently are capable of delivering the phylogenetic resolution or coverage of $16 \mathrm{~S}$ rRNA surveys. Using such surveys and comprehensive geochemical datasets as hypothesis-generating and -refining tools, one can better constrain the putative redox adaptation of different microbial clades, and thus the role redox adaptation may play as an evolutionary force that shapes the biogeography of deep 16S rRNA clades. One approach would be to examine the hierarchical level at which phylogenetic lineages assort between sediments where the same electron acceptors persist in different environmental contexts, e.g., the spatially expanded suboxic/oxic strata of abyssal sediments and the spatially compressed suboxic/oxic strata perched on top of deep anoxic sediments, or even metal oxides persisting into euxinic sediments. This would allow examination whether factors such as reductant/oxidant concentration or sediment redox potential, as distinct from electron acceptor availability, play key roles in redox adaptation, possibly in determining the type of biosynthetic pathways utilized.

Big-picture studies examining the deep phylogeography of microbes have established that deeply rooted clades indeed assort according to habitat (von Mering et al., 2007), and have additionally revealed several factors that may explain some of the variance observed in archaeal biogeography, with the most 
important habitat-defining distinctions being salinity and terrestrial vs. aquatic (Auguet et al., 2010). Microbial biogeography has also been explored by focusing on a specific subset of environmental parameters that are hypothesized to determine habitat specialization, revealing, for example, that carbon lability differences between soils correlate with the relative abundance of different bacterial phyla, observations which are in line with hypotheses about the physiology of "copiotroph" or "oligotroph" organisms (Fierer et al., 2007). In a similar fashion, the current review proceeds from the hypothesis that marine sediments of different redox state represent different habitat niches for microbes, and examines the patterns of community membership and abundance across these putative distinct habitats. The definition of distinct redox habitats implies specific microbial activities and physiologies in each habitat; thus, working hypotheses on microbial function emerge from the analysis of diversity patterns across these habitats. However, when comparing different environments defined operationally by one or a few variables, it should be kept in mind that other parameters may co-vary. For example, the freshwatersaltwater biogeographic divide which appears to be rarely crossed in evolution (Logares et al., 2009; Auguet et al., 2010) could be maintained due to differences in exterior osmotic pressure, sulfur compound availability, carbonate speciation, $\mathrm{pH}$, or biosynthetic requirements. Caution in overinterpreting the functional significance of biogeographic patterns is warranted.

\section{CONCLUSION}

Archaeal communities undergo a marked shift along gradients of sediment trophic state. Archaeal lineages found in oligotrophic, oxidized sediments significantly expand the higher-order taxonomic diversity within the Archaea. These lineages have most often been found in other environments that are suboxic or oxic, with some proportion occupying habitats of ambiguous redox state, or primarily anoxic habitats that contains partially oxidized microniches (organic-rich surficial sediments). Such a lineage distribution is consistent with redox specialization determining in large part the distribution of archaeal lineages in the marine subsurface. Since the phylogenetic groups associated with this diversity shift were deeply branching (possibly class or phylum level), redox specialization could represent a fundamental correlate with deep phylogenetic diversification within the archaeal domain. Further studies are needed to resolve the phylogenetic placement of these novel lineages, as well as to explore the how the defining characteristics of oligotrophic sediments - nutrient limitation, oxidized environmental redox state, and availability of high-energy electron acceptors - have shaped archaeal evolution.

\section{METHODS FOR SAMPLING, NUCLEIC ACID EXTRACTION, AND DIVERSITY ANALYSIS}

This study reanalyzes archaeal $16 \mathrm{~S}$ rRNA sequences from gravity cores at site SPG12, sampled during Cruise Knox02RR to the South Pacific Gyre (D’Hondt et al., 2009; Durbin and Teske, 2010, 2011). Additional published sequences from different marine sediments were used for this study (Table 2); the published sampling procedures are briefly summarized here. Archaeal 16S rRNA gene sequences for the Mediterranean cold seeps were derived from the upper $20-30 \mathrm{~cm}$ sediments, which were subsampled from a box core using aluminum cores and divided into two or three subsections before freezing (Heijs et al., 2008). Samples from the South China Sea were retrieved via gravity coring and subsampling from the center of the split cores (Wang et al., 2010a), while sediments from the Coral Sea were sampled via piston core and aseptically subsampled (Roussel et al., 2009). Archaeal 16S rRNA gene sequences from SPG12 were extracted and amplified from sediments subsampled from gravity core sections using a sterilized cut-off syringe, at a sampling resolution of $10 \mathrm{~cm}$. Archaeal 16S rRNA gene sequences for the Gulf of Mexico IODP 308 samples were obtained from advanced piston-cored and XCB-cored sediments at depth horizons 4.45, 12.0, and $77 \mathrm{~m}$ of the Brazos Basin core U1319A; and at four depths $(2.9,7.4,13.9$, and ca. $28 \mathrm{~m})$ within the sulfate-reducing zone, and 92.4, 226.9, and $256.0 \mathrm{~m}$ of Brazos Basin core U1320A (Nunoura et al., 2009). Archaeal $16 \mathrm{~S}$ sequences for the Peru Margin ODP sites were derived from the upper sulfate-methane transition zone (SMTZ) at site 1227 (37.8 mbsf, Biddle et al., 2006; 35.35, 34.25, 37.75, and 40.35 mbsf, Sørensen and Teske, 2006), as well as intervals above and below the SMTZ (6.55, 7.35, 21.35, 45.35 mbsf; Sørensen and Teske, 2006). Sequences from site 1229 were obtained from the upper and lower SMTZs at 29.4/30.2 and 86.8/86.67, mbsf respectively (Parkes et al., 2005; Biddle et al., 2006), as well as from 6.7 and 42.03 mbsf (Parkes et al., 2005). Site 1230 was sampled at $11.0 \mathrm{mbsf}$ near the SMTZ (Biddle et al., 2006). ODP site 1226 was sampled from approximately $1.3,7.2,26.2$, and $45.2 \mathrm{mbsf}$; methane and sulfate coexist throughout the sediment column and suggest that both methanogenesis and sulfate reduction occur. Finally, ODP sites 1244, 1245, and 1251 were sampled mostly below the SMTZ, from $0.45,6.7$, $16.2,31.2$, and $129.2 \mathrm{mbsf}$ (1244), 157.9 and $194.7 \mathrm{mbsf}$ (1245), and $4.5,22.7,43.2,64.2,82.7,104.5,123.1,142.2,169.9,179.9$, 204.2, 228.2, and 330.6 mbsf (Nunoura et al., 2008).

\section{DIVERSITY SURVEY METHODS}

While all studies used slightly different nucleic acid extraction protocols (Table 2), most involved chemical cell-membrane disruption with sodium dodecyl sulfate (SDS), mechanical membrane disruption with bead beating, and phenol-chloroform extraction (e.g., Zhou et al., 1996). The sites with the largest sample size and most extensive geochemical data, i.e., SPG12, the Peru Margin and Peru Basin sites, and the Mediterranean cold seeps, all used some variation of a SDS/bead beating/phenol-chloroform based extraction protocol, although some sequences from 1231 were only amplified using an enzymatic-lysis + SDS based extraction (Sørensen et al., 2004). Primers used for 16S rRNA gene amplification differed within and between oligotrophic, mesotrophic, and eutrophic sediments. Primer and PCR bias undoubtedly plays an important, but unknown role in the between-library differences observed for all libraries. Finally, although amplicon size has been shown to influence clone library composition, all amplicons considered here fell into a size range from 850 or 900 nucleotides to 1500 nucleotides (Table 2) in which variation in amplicon size minimally impacts clone library composition (Huber et al., 2009).

\section{DATABASE SEARCHES AND PHYLOGENETIC IDENTIFICATION}

A search for all available Archaeal $16 \mathrm{~S}$ sequences from oligotrophic marine sediment sites was conducted first by identifying closest relatives to SPG12 Archaeal sequences via BLAST searches and searches within the ARB v.95 REF 16S/18S database (Pruesse 
et al., 2007). If a sequence was derived from an oligotrophic sediment environment, defined as any marine benthic environment not situated on a continental slope or shelf, all sequences from the associated publication were imported and aligned in ARB (Ludwig et al., 2004). Any closest relatives presented in the associated publication were also imported and aligned. Further internet searches using keywords yielded no additional publications. Studies with archived sequence reads or published abundances of representative phylotypes were then used for comparative analysis. The archaeal ARB file is available from the authors on request (amdurbin@gmail.com; teske@email.unc.edu) or online at http://jmartiny.bio.uci.edu/lab/Data.html.

For all earlier clades subsumed by a later taxonomy, the original definition is depicted, unless the later, subsuming taxonomy significantly expanded or changed the original definition, in which case both are depicted; however, only phylogenetically valid clades were depicted. For example, the GreenGene 2006/2008 taxonomy (DeSantis et al., 2006) subsumed some identical taxonomic designations of Hugenholtz (2002); when valid clades shared the same name but phylogenetically differed between these two taxonomies, both definitions are given. We used the GreenGenes taxonomy according to the November 2008 GreenGenes version (greengenes236469.arb.gz, downloadable from http://greengenes.lbl. gov/Download/Sequence_Data/Arb_databases/), which differed from the original GreenGenes release (DeSantis et al., 2006) by adding a few novel designations. The GreenGenes 2011 release differed substantially from the 2008 release in that it removed many GreenGenes 2008 designations, and added, modified, or kept unmodified relatively few. In this case, only the 2011 additions or modifications were noted according to their 2011 definitions

\section{REFERENCES}

Agogué, H., Brink, M., Dinasquet, J., and Herndl, G. J. (2008). Major gradients in putatively nitrifying and nonnitrifying Archaea in the deep North Atlantic. Nature 456, 788-792.

Amend, J. P., and Shock, E. L. (1998). Energetics of amino acid synthesis in hydrothermal ecosystems. Science 281, 1659-1662.

Ashelford, K. E., Chuzhanova, N. A., Fry, J. C., Jones, A. J., and Weightman, A. J. (2005). At least 1 in 20,16S rRNA sequence records currently held in public repositories is estimated to contain substantial anomalies. Appl. Environ. Microbiol. 71, 7724-7736.

Auguet, J.-C., Barberan, A., and Casamayor, E. O. (2010). Global ecological patterns in uncultured Archaea. ISME J. 4, 182-190.

Baker, B. J., Comolli, L. R., Dick, G. J., Hauser, L. J., Hyatt, D., Dill, B. D., Land, M. L., VerBerkmoes, N. C., Hettich, R. L., and Banfield, J. F. (2010). Enigmatic, ultrasmall, uncultivated archaea. Proc. Natl. Acad. Sci. U.S.A. 107, 8806-8811.

Berner, R. A. (1981). A new geochemical classification of sedimentary environments. J. Sed. Petrol. 51, 359-365.
Biddle, J. F., Fitz-Gibbon, S., Schuster, S. C., Brenchley, J. E., and House, C. H. (2008). Metagenomic signatures of the Peru Margin subseafloor biosphere show a genetically distinct environment. Proc. Natl. Acad. Sci. U.S.A. 105, 10583-10588.

Biddle, J. F., Lipp, J. S., Lever, M. A., Lloyd, K. G., Sørensen, K. B., Anderson, R., Fredricks, H. F., Elvert, M., Kelly, T. J., Schrag, D. P., Sogin, M. L., Brenchley, J. E., Teske, A., House, C. H., and Hinrichs, K.U. (2006). Heterotrophic Archaea dominate sedimentary subsurface ecosystems off Peru. Proc. Natl. Acad. Sci. U.S.A. 103, 3846-3851.

Biddle, J. F., White, J. R., Teske, A. P., and House, C. H. (2011). Metagenomics of the subsurface BrazosTrinity Basin (IODP site 1320): comparison with other sediment and pyrosequenced metagenomes. ISME J 5, 108-1047.

Boussau, B., and Gouy, M. (2006). Efficient likelihood computations with nonreversible models of evolution. Syst. Biol. 55, 756-768.

Brochier-Armanet, C., Boussau, B., Gribaldo, S., and Forterre, P. (2008). Mesophilic Crenarchaeota: proposal for a third archaeal phylum, the

(McDonald et al., 2011), while those designations common to both versions were noted according to the GreenGenes 2008 release (Table 3).

For the Thermoplasmata-affiliated sequences (Figure 5), a lack of monophyletic clades defined for this group was addressed via an extensive analysis including all diversity represented by $16 \mathrm{~S}$ rRNA gene sequences $>1000$ bp available in SILVA v.106. In constructing this tree, the primary goal was to create the deepest stable clades achievable using an alignment $\sim 1000 \mathrm{bp}$ and minimal chimera screening beyond that already performed by SILVA's Pintail screening, by removing sequences that appear to destabilize clades, avoiding clades with shallow internal branch lengths relative to terminal branch lengths. After amending monophyletic clades with new sequences, the newly populated and expanded clade should be as consistent as its earlier version, with stable bootstrap support and with the same intergroup distance to the neighbor clades. Statistical support was estimated with 500 maximum likelihood bootstrap replications using TreeFinder (Jobb et al., 2004).

\section{ACKNOWLEDGMENTS}

This study was supported by the NASA Astrobiology Institutes "Environmental genomes" (NCC 2-1054), "Subsurface biospheres" (NCC 2-1275), and by NSF (NSF-Ocean Drilling Program 0527167). Andreas Teske was further supported by a Hanse Institute Fellowship, and by the Center for Dark Energy Biosphere Investigations (C-DEBI). We thank Jennifer Biddle, Amanda Martino, and Chris House for the summary on the archaeal communities in ODP site 1226 (Figure 4), and Marc Alperin for a thoughtful reading of the manuscript.

Thaumarchaeota. Nat. Rev. Microbiol. 6, 245-252.

Cadillo-Quiroz, H., Brauer, S., Yashiro, E., Sun, Christine, Yavitt, J., and Zinder, S. (2006). Vertical profiles of methanogenesis and methanogens in two contrasting acidic peatlands in central New York State, USA. Environ. Microbiol. 8, 1428-1440.

Chouari, R., Le Paslier, D., Dauga, C., Daegelen, P., Weissenbach, J., and Sghir, A. (2005). Novel major bacterial candidate division within a municipal anaerobic sludge digester. Appl. Environ. Microbiol. 71, 2145-2153.

Church, M. J., DeLong, E. F., Ducklow, H. W., Karner, M. B., Preston, C. M., and Karl, D. M. (2003). Abundance and distribution of planktonic Archaea and Bacteria in the waters west of the Antarctic Peninsula. Limnol. Oceanogr. 48, 1893-1902.

Conrad, R. (1996). Soil microorganisms as controllers of atmospheric trace gases $\left(\mathrm{H}_{2}, \mathrm{CO}, \mathrm{CH}_{4}, \mathrm{OCS}, \mathrm{N}_{2} \mathrm{O}\right.$, and NO). Microbiol. Rev. 60, 609-640.

DeLong, E. F. (1992). Archaea in coastal marine environments. Proc. Natl. Acad. Sci. U.S.A. 89, 5685-5689.

DeSantis, T. Z., Hugenholtz, P., Larsen, N., Rojas, M., Brodie, E. L., Keller,
K., Huber, T., Dalevi, D., Hu, P., and Andersen, G. L. (2006). Greengenes, a chimera-checked 16S rRNA gene database and workbench compatible with ARB. Appl. Environ. Microbiol. 72, 5069-5072.

Dhillon, A., Lever, M., Lloyd, K., Albert, D. B., Sogin, M. L., and Teske, A. (2005). Methanogen diversity evidenced by molecular characterization of methyl coenzyme $\mathrm{M}$ reductase A (mcrA) genes (mcrA) in hydrothermal sediments of the guaymas basin. Appl. Environ. Microbiol. 71, 4592-4601.

D’Hondt, S., Jørgensen, B. B., Miller, D. J., Batzke, A., Blake, R., Cragg, B. A., Cypionka, H., Dickens, G. R., Ferdelman, T., Hinrichs, K.U., Holm, N. G., Mitterer, R., Spivack, A., Wang, G., Bekins, B., Engelen, B., Ford, K., Gettemy, G., Rutherford, S. D., Sass, H., Skilbeck, C. G., Aiello, I. W., Gurin, G., House, C. H., Inagaki, F., Meister P., Naehr, T., Niitsuma, S., Parkes, R. J., Schippers, A., Smith, D. C., Teske, A., Wiegel, J., Padilla, C. N., and Acosta, J. L. S. (2004). Distribution of microbial activities in deep subseafloor sediments. Science 306, 2216-2221. 
D'Hondt, S., Rutherford, S., and Spivack, A. J. (2002). Metabolic activity of subsurface life in deep-sea sediments. Science 295, 2067-2070.

D'Hondt, S., Spivack, A. J., Pockalny, R., Ferdelman, T. G., Fischer, J. P., Kallmeyer, J., Abrams, L. J., Smith, D. C., Graham, D., Hasiuk, F., Schrum, H., and Stancin, A. M. (2009). Subseafloor sedimentary life in the South Pacific Gyre. Proc. Natl. Acad. Sci. U.S.A. 106, 11651-11656.

Dias, A. S., and Barriga, F. J. A. S. (2006). Mineralogy and geochemistry of hydrothermal sediments from the serpentinite-hosted Saldanha hydrothermal field $\left(36^{\circ} 34^{\prime} \mathrm{N}\right.$; $\left.33^{\circ} 26^{\prime} \mathrm{W}\right)$ at MAR. Mar. Geol. 225, 157-175.

Dick, G. J., Andersson, A. F., Baker, B. J., Simmons, S. S., Thomas, B. C., Yelton, A. P., and Banfield, J. F. (2009). Community-wide analysis of microbial genome sequence signatures. Genome Biol. 10, R85.

Dickens, G., Exon, N., Holdway, D., Lafoy, Y., Auzende, J. M., Dunbar, G., and Summons, R. (2001). Quaternary Sediment Cores from the Southern Fairway Basin on the Northern Lord Howe Rise (Tasman Sea), AGSO-Geoscience Australia, Record 2001/31. Canberra, Australia.

Dunne, J. P., Sarmiento, J. L., and Gnanadesikan, A. (2007). A synthesis of global particle export from the surface ocean and cycling through the ocean interior and on the seafloor. Global Biogeochem. Cycles 21, GB4006.

Durbin, A. M., Biddle, J. F., Martino, A., House, C., Fischer, J., Spivack, A., Schrum, H., D'Hondt, S., and Teske, A. (2009). Microbial community stratification in TOC-depleted marine subsurface sediments of the Pacific Ocean. Geochem. Cosmochim. Acta 73 (Suppl.), A316.

Durbin, A. M., and Teske, A. (2010). Sediment-associated microdiversity within the Marine Group I Crenarchaeota. Environ. Microbiol. Rep. 2, 693-703.

Durbin, A. M., and Teske, A. (2011). Microbial diversity and stratification of oligotrophic abyssal South Pacific sediments. Environ. Microbiol. 13, 3219-3234.

Eder, W., Schmidt, M., Koch, M., Garbe-Schönberg, D., and Huber, R. (2002). Prokaryotic phylogenetic diversity and corresponding geochemical data of the brine-seawater interface of the Shaban Deep, Red Sea. Environ. Microbiol. 4, 758-763.

Expedition 308 Scientists. (2006a). "Site U1319," in Proceedings of the Integrated Ocean Drilling Program 308, eds P. B. Flemings, J. H. Behrmann, C. M. John, and the Expedition 308 Scientists (College Station, TX: Integrated Ocean Drilling Program Management International, Inc.).

Expedition 308 Scientists. (2006b). "Site U1320," in Proceedings of the Integrated Ocean Drilling Program 308, eds P. B. Flemings, J. H. Behrmann, C. M. John, and the Expedition 308 Scientists (College Station, TX: Integrated Ocean Drilling Program Management International, Inc.).

Fierer, N., Bradford, M. A., and Jackson, R. B. (2007). Toward an ecological classification of soil bacteria. Ecology $88,1354-1364$.

Fredrickson, J. K., Zachara, J. M., Kennedy, D. W., Dong, H., Onstott, T., Hinman, N. W., and Li, S.-M. (1998). Biogenic iron mineralization accompanying the dissimilatory reduction of hydrous ferric oxide by a groundwater bacterium. Geochim. Cosmochim. Acta 62, 3239-3257.

Fry, J. C., Parkes, R. J., Cragg, B. A., Weightman, A. J., and Webster, G. (2008). Prokaryotic biodiversity and activity in the deep subseafloor biosphere. FEMS Microbiol. Ecol. 66, 181-196.

Fuhrman, J. A., and Davis, A. A. (1997). Widespread Archaea and novel Bacteria from the deep sea as shown by $16 \mathrm{~S}$ rRNA gene sequences. Mar. Ecol. Prog. Ser. 150, 275-285.

Fuhrman, J. A., McCallum, K., and Davis, A. A. (1992). Novel major archaebacterial group from marine plankton. Nature 356, 148-149.

Gieskes, J. M., and Boulègue, J. (1986). "Interstitial water studies, Leg 92," in Initial Reports Deep Sea Drilling Project 92, eds M. Leinen, D. K. Rea, R. N. Anderson, K. Becker, J. J. Boulègue, J. Erzinger, J. M. Gieskes, D. Goldberg, M. Goldfarb, R. Goldsborough, M. A. Hobart, M. Kastner, S. Knuettel, M. W. Lyle, D. Moos, R. Newmark, T. Nishatani, R. M. Owen, J. A. Pearce, K. Romine, and R. A. Stephan (Washington: US Government Printing Office), 423-429.

Gillan, D. C., and Danis, B. (2007). The archaebacterial communities in Antarctic bathypelagic sediments. Deep Sea Res. II 54, 1682-1690.

Glud, R. N. (2008). Oxygen dynamics of marine sediments. Mar. Biol. Res. 4, 243-289.

Großkopf, R., Janssen P. H., and Liesack, W. (1998a). Diversity and structure of the methanogenic community in anoxic rice paddy soil microcosms as examined by cultivation and direct 16S rRNA gene sequence retrieval. Appl. Environ. Microbiol. 64, 960969.
Großkopf, R., Stubner, S., and Liesack, W. (1998b). Novel euryarchaeotal lineages detected on rice roots and in the anoxic bulk soil of flooded rice microcosms. Appl. Environ. Microbiol. 64, 4983-4989.

Hales, B. A., Edwards, C., Ritchie, D. A., Hall, G., Pickup, R. W., and Saunders, J. R. (1996). Isolation and identification of methanogenspecific DNA from blanket bog peat by PCR amplification and sequence analysis. Appl. Environ. Microbiol. 62, 668-675.

Heijs, S. K., Laverman, A. M., Forney, L. J., Hardoim, P. R., and Van Elsas, J. D. (2008). Comparison of deep-sea sediment microbial communities in the Eastern Mediterranean. FEMS Microbiol. Ecol. 64, 362-377.

Hinrichs, K.-U., and Hayes, J. M., Sylva, S. P., Brewer, P. G., and DeLong, E. F. (1999). Methane-consuming archaebacteria in marine sediments. Nature 398, 802-805.

Huber, J. A., Morrison, S. M., Neal, P. R., Sogin, M. L., and Welch, M. D. B. (2009). Effect of PCR amplicon size on assessments of clone library microbial diversity and community structure. Environ. Microbiol. 11, 1292-1302.

Hugenholtz, P. (2002). Exploring prokaryotic diversity in the genomic era. Genome Biol. 3, reviews0003-reviews0003.8.

Hugenholtz, P., and Huber, T. (2003) Chimeric 16S rDNA sequences of diverse origin are accumulating in the public databases. Int. J. Syst. Evol. Microbiol. 53, 289-293.

Hutchison, C. S. (2004). Marginal basin evolution: the southern South China Sea. Mar. Pet. Geol. 21, 1129-1148.

Inagaki, F., Nunoura, T., Nakagawa, S. Teske,A., Lever, M., Lauer, A., Suzuki, M., Takai, K., Delwiche, M., Colwell, F. S., Nealson, K. H., Horikoshi, K., D'Hondt, S., and Jorgensen, B. B. (2006). Biogeographical distribution and diversity of microbes in methane hydrate-bearing deep marine sediments on the Pacific Ocean Margin. Proc. Natl. Acad. Sci. U.S.A. 103, 2815-2820.

Inagaki, F., Suzuki, M., Takai, K., Oida, H., Sakamoto, T., Aoki, K., Nealson, K. H., and Horikoshi, K. (2003). Microbial communities associated with geological horizons in coastal subseafloor sediments from the Sea of Okhotsk. Appl. Environ. Microbiol. 69, 7224-7235.

Inagaki, F., Takai, K., Komatsu, T., Kanamatsu, T., Fujiioka, K., and Horikoshi, K. (2001). Archaeology of Archaea: geomicrobiological record of Pleistocene thermal events concealed in a deep-sea subseafloor environment. Extremophiles 5, 385-392.

Jahnke, L. L., Orphan, V. J., Embaye, T., Turk, K. A., Kubo, M. D., Summons, R. E., and DesMarais, D. J. (2008). Lipid biomarker and phylogenetic analyses to reveal archaeal biodiversity and distribution in hypersaline microbial mat and underlying sediment. Geobiology 6, 394-410.

Jakobsen, R. (2007). Redox microniches in groundwater: a model study on the geometric and kinetic conditions required for concomitant $\mathrm{Fe}$ oxide reduction, sulfate reduction, and methanogenesis. Water Resour. Res. 43, W12S12.

Jobb, G., von Haeseler, A., and Strimmer, K. (2004). TREEFINDER: a powerful graphical analysis environment for molecular phylogenetics. BMC Evol. Biol. 4, 18. doi:10.1186/1471-2148-4-18

Jørgensen, B. B. (1977). Bacterial sulfate reduction within reduced microniches of oxidized marine sediments. Mar. Biol. 4, 7-17.

Jørgensen, B. B. (2011). Deep subseafloor microbial cells on physiological standby. Proc. Natl. Acad. Sci. U.S.A. 108, 18193-18194.

Jørgensen, B. B., Glud, R. N., and Holby, O. (2005). Oxygen distribution and bioirrigation in Arctic fjord sediments (Svalbard, Barents Sea). Mar. Ecol. Prog. Ser. 292, 89-95.

Jurgens, G., Glöckner, F.-O., Amann, R., Saano, A., Montonen, L., Likolammi, M., and Münster, U. (2000). Identification of novel Archaea in bacterioplankton of a boreal forest lake by phylogenetic analysis and fluorescent in situ hybridization. FEMS Microbiol. Ecol. 34, 45-56.

Karner, M. B., DeLong, E. F., and Karl, D. M. (2001). Archaeal dominance in the mesopelagic zone of the Pacific Ocean. Nature 409, 507-510.

Kendall, M. M., Wardlaw, G. D., Tang, C. F., Bonin, A. S., Liu, Y., and Valentine, D. L. (2007). Diversity of Archaea in marine sediments from Skan Bay, Alaska, including cultivated methanogens, and description of Methanogenium boonei sp. nov. Appl. Environ. Microbiol. 73, 407-414.

Knittel, K., Lösekann, T., Boetius, A., Kort, R., and Amann, R. (2005). Diversity and distribution of methanotrophic archaea at Cold Seeps. Appl. Environ. Microbiol. 71, 467-479.

König, I., Drodt, M., Suess, E., and Trautwein, A. X. (1997). Iron reduction through the tan-green 
color transition in deep-sea sediments. Geochim. Cosmochim. Acta 61, 1679-1683.

König, I., Haeckel, M., Drodt, M., Suess, E., and Trautwein, A. X. (1999). Reactive $\mathrm{Fe}(\mathrm{II})$ layers in deep-sea sediments. Geochim. Cosmochim. Acta 63, 1517-1526.

Kormas, K. A., Meziti, A., Dählmann, A., De Lange, G. J., and Lykousis, V. (2008). Characterization of methanogenic and prokaryotic assemblages based on mcrA and $16 \mathrm{~S}$ rRNA gene diversity in sediments of the Kazan mud volcano (Mediterranean Sea). Geobiology 6, 450-460.

Kubo, K., Lloyd, K., Biddle, J. F., Amann, R., Teske, A., and Knittel, K. (2012). Archaea of the Miscellaneous Crenarchaeotal Group (MCG) are abundant, diverse and widespread in marine sediments. ISME J. doi: 10.1038/ismej.2012.37

Lane, D. J. (1991). "16S/23S rRNA sequencing," in Nucleic Acid Techniques in Bacterial Systematics, eds E. Stackebrandt and M. Goodfellow (New York: John Wiley \& Sons), 115-148.

Lever, M. A., Heuer, V. B., Morono, Y., Masui, N., Schmidt, F., Alperin, M. J., Inagaki, F., Hinrichs, K.-U., and Teske, A. (2010). Acetogenesis in deep subseafloor sediments of the Juan de Fuca ridge flank: a synthesis of geochemical, thermodynamic, and gene-based evidence. Geomicrobiol. J. 27, 183-211.

Li, Y., Li, F., Zhang, X., Qin, S., Zeng, Z., Dang, H., and Qin, Y. (2008). Vertical distribution of bacterial and archaeal communities along discrete layers of a deep-sea cold sediment sample at the East Pacific Rise $\left(13^{\circ} \mathrm{N}\right)$. Extremophiles 12, 575-585.

Liao, L., Xu, X-W., Jiang, X. W., Wang, C. S., Zhang, D. S., Ni, J. Y., and Wu, M. (2011). Microbial diversity in deepsea sediment from the cobalt-rich crust deposit region in the Pacific Ocean. FEMS Microbiol. Ecol. 78, 565-585.

Lipp, J. S., Morono, Y., Inagaki, F., and Hinrichs, K.-U. (2008). Significant contribution of Archaea to extant biomass in marine subsurface sediments. Nature 454, 991-994.

Logares, R., Bråte, J., Bertilsson, S., Clasen, J. L., Shalchian-Tabrizi, K., and Rengefors, K. (2009). Infrequent marine-freshwater transitions in the microbial world. Trends Microbiol. 17, 414-422.

López-Garcia, P., Rodriguez-Valera, F., Pedrós-Aliós, C., and Moreira, D. (2001). Unexpected diversity of small eukaryotes in deep-sea
Antarctic plankton. Nature 409, 603-607.

Lovley, D. R., and Goodwin, S. (1988). Hydrogen concentrations as an indicator of the predominant terminal electron-accepting reactions in aquatic sediments. Geochim. Cosmochim. Acta 52, 2993-3003.

Ludwig, W., Strunk, O., Westram, R., Richter, L., Meier, H., Yadhukumar, K., Buchner, A., Lai, T., Steppi, S., Jobb, G., Förster, W., Brettske, I., Gerber, S., Ginhart, A. W., Gross, O., Grumann, S., Hermann, S., Jost, R., König, A., Liss, T., Lüßmann, R., May, M., Nonhoff, B., Reichel, B., Strehlow, R., Stamatakis, A., Stuckmann, N., Vilbig, A., Lenke, M., Ludwig, T., Bode, A., and Schleifer, K.-H. (2004). ARB: a software environment for sequence data. Nucleic Acids Res. 32, 1363-1371.

Mäkelä, K., and Tuominen, L. (2003). Pore water nutrient profiles and dynamics in soft bottoms of the northern Baltic Sea. Hydrobiologia 492, 43-53.

Martens-Habbena, W., Berube, P. M., Urakawa, H., de la Torre, J. R., and Stahl, D. A. (2009). Ammonia oxidation kinetics determine niche separation of nitrifying Archaea and Bacteria. Nature 461, 976-981.

McCollom, T. M., and Amend, J. P. (2005). A thermodynamic assessment of energy requirements for biomass synthesis by chemolithoautotrophic microorganisms in oxic and anoxic environments. Geobiology 3, 135-144.

McDonald, D., Price, M. N., Goodrich, J., Nawrocki, E. P., DeSantis, T. Z., Probst, A., Andersen, G. L., Knight, R., and Hugenholtz, P. (2011). An improved Greengenes taxonomy with explicit ranks for ecological and evolutionary analyses of bacteria and archaea. ISME J. 6, 610-618.

McInerney, M. J., and Beaty, P. S. (1988). Anaerobic community structure from a nonequilibrium thermodynamic perspective. Can. J. Microbiol. 34, 487-493.

Narasingarao, P., Podell, S., Ugalde, J. A., Brochier-Armanet, C., Emerson, J. B., Brocks, J. J., Heidelberg, K. B., Banfield, J. F., and Allen, E. E. (2012). De novo metagenomic assembly reveals abundant novel major lineage of Archaea in hypersaline microbial communities. ISME J. 6, 81-93.

Nercessian, O., Fouquet, Y., Pierre, C., Prieur, D., and Jeanthon, C. (2005). Diversity of Bacteria and Archaea associated with carbonate-rich metalliferous sediment sample from the
Rainbow vent field on the MidAtlantic Ridge. Environ. Microbiol. 7 , 698-714.

Nercessian, O., Reysenbach, A.-L., Prieur, D., and Jeanthon, C. (2003). Archaeal diversity associated with in situ samplers deployed on hydrothermal vents on the East Pacific Rise $\left(13^{\circ} \mathrm{N}\right)$. Environ. Microbiol. 5, 492-502.

Nunoura, T., Hirayama, H., Takami, H. Oida, H., Nishi, S., Shimamura, S. Suzuki, Y., Inagaki, F., Takai, K., Nealson, K. H., and Horikoshi, K. (2005). Genetic and functional properties of uncultivated thermophilic crenarchaeotes from a subsurface gold mine as revealed by analysis of genome fragments. Environ. Microbiol. 7, 1967-1984.

Nunoura, T., Inagaki, F., Delwiche, M. E., Colwell, F. S., and Takai, K. (2008). Subseafloor microbial communities in methane hydratebearing sediment at two distinct locations (ODP Leg 204) in the Cascadia Margin. Microbes Environ. 23, 317-325.

Nunoura, T., Soffientino, B., Blazejak, A., Kakuta, J., Oida, H., Schippers, A., and Takai, K. (2009). Subseafloor microbial communities associated with rapid turbidite deposition in the Gulf of Mexico continental slope (IODP Expedition 308). FEMS Microbiol. Ecol. 69, 410-424.

Ochsenreiter, T., Selezi, D., Quaiser, A., Bonch-Osmolovskaya, L., and Schleper, C. (2003). Diversity and abundance of Crenarchaeota in terrestrial habitats studied by $16 \mathrm{~S}$ RNA surveys and real time PCR. Environ. Microbiol. 5, 787-797.

Orphan, V. J., Hinrichs, K.-U., Paull, C. K., Taylor, L. T., Sylva, S., and DeLong, E. F. (2001). Comparative analysis of methane-oxidizing archaea and sulfate-reducing bacteria in anoxic marine sediments. Appl. Environ. Microbiol. 67, 1922-1934.

Pagé, A., Juniper, S. K., Olagnon, M., Alain, K., Desrosiers, G., Quérellou, J., and Cambon-Bonavita, M.-A. (2004). Microbial diversity associated with a Paralvinella sulfincola tube and the adjacent substratum on an active deep-sea vent chimney. Geobiology 2, 225-238.

Parkes, R. J., Cragg, B. A., Bale, S. J., Getliff, J. M., Goodman, K., Rochelle, P. A., Fry, J. C., Weightman, A. J., and Harvey, S. M. (1994). Deep bacterial biosphere in Pacific Ocean sediments. Nature 371, 410-413.

Parkes, R. J., Webster, G., Cragg, B. A., Weightman, A. J., Newberry,
C. J., Ferdelman, T. G., Kallmeyer, J., Jørgensen, B. B., Aiello, I. W., and Fry, J. C. (2005). Deep subseafloor prokaryotes stimulated at interfaces over geologic time. Nature 436, 390-394.

Pester, M., Schleper, C., and Wagner, M. (2011). The Thaumarchaeota: an emerging view of their phylogeny and ecophysiology. Curr. Opin. Microbiol. 14, 300-306.

Postma, D., and Jakobsen, R. (1996). Redox zonation: equilibrium constraints on the $\mathrm{Fe}(\mathrm{III}) / \mathrm{SO} 4$ reduction interface. Geochim. Cosmochim. Acta 17, 3169-3175.

Poulton, S. W., and Raiswell, R. (2002). The low-temperature geochemical cycle of iron: from continental fluxes to marine sediment deposition. Am. J. Sci. 302, 774-805.

Pruesse, E., Quast, C., Knittel, K., Fuchs, B. M., Ludwig, W., Peplies, J., and Glöckner, F. O. (2007). SILVA: a comprehensive online resource for quality checked and aligned ribosomal RNA sequence data compatible with ARB. Nucleic Acids Res. 35, 7188-7196.

Reed, D., Fujita, Y., Delwiche, M. E., Blackwelder, D. B., Sheridan, P. P., and Uchida, T. Colwell, F. S. (2002). Microbial communities from methane hydrate-bearing deep marine sediments in a forearc basin. Appl. Environ. Microbiol. 68, 3759-3770

Robertson, C. E., Spear, J. R., Harris, J. K., and Pace, N. R. (2009). Diversity and stratification of archaea in a hypersaline microbial mat. Appl. Environ. Microbiol. 75, 1801-1810.

Rogers, K. L., and Amend, J. P. (2006). Archaeal diversity and geochemical energy yields in a geothermal well on Vulcano Island, Italy. Geobiology 3, 319-322.

Roussel, E. G., Sauvadet, A.-L., Chaduteau, C., Fouquet, Y., Charlou, J.-L., Prieur, D., and Bonavita, M.-A. C. (2009). Archaeal communities associated with shallow to deep subseaflorr sediments of the New Caledonia Basin. Environ. Microbiol. 11, 2446-2462.

Schleper, C., Jurgens, G., and Jonuscheit, M. (2005). Genomic studies of uncultivated archaea. Nat. Rev. Microbiol. 3, 479-488.

Schleper, C., and Nicol, G. W. (2010). Ammonia-oxidizing archaea - physiology, ecology and evolution. Adv. Microb. Physiol. 57, 1-41.

Seiter, K., Hensen, C., Schroter, J., and Zabel, M. (2004). Organic carbon content in surface sedimentsdefining regional provinces. Deep Sea Res. I 51, 2001-2026. 
Severmann, S., Mills, R. A., Palmer, M. R., Telling, J. P., Cragg, B., and Parkes, R. J. (2006). The role of prokaryotes in subsurface weathering of hydrothermal sediments: a combined geochemical and microbiological investigation. Geochim. Cosmochim. Acta 70, 1677-1694.

Shipboard Scientific Party. (1976). "Site 321," in Initial Reports Deep Sea Drilling Project 34, eds R. S. Yeats, S. R., Hart, J. M. Ade-Hall, M. N. Bass, W. E. Benson, R. A. Hart, P. G. Quilty, H. M. Sachs, M. H. Salisbury, and T. L. Valier (Washington: Government Printing Office), 111-153.

Shipboard Scientific Party. (1988a). "Site 684," in Proceedings of the Ocean Drilling Program, Initial Reports 112, eds E. Suess, R. von Huene, K.-C. Emeis, J. Bourgois, J. d. C. CruzadoCastañeda, P. De Wever, G. Eglinton, R. Garrison, M. Greenberg, E. H. Paz, P. Hill, M. Ibaraki, M. Kastner, A. E. S. Kemp, K. Kvenvolden, R. Langridge, N. LindsleyGriffin, J. Marsters, E. Martini, R. McCabe, L. Ocola, J. Resig, A. Q. Sanchez-Fernandez, H.-J. Schrader, T. Thornburg, G. Wefer and M. Yamano (College Station: Ocean Drilling Program), 525-596.

Shipboard Scientific Party. (1988b). "Site 681," in Proceedings of the Ocean Drilling Program, Initial Reports 112, eds E. Suess, R. von Huene, K.-C. Emeis, J. Bourgois, J. d. C. CruzadoCastañeda, P. De Wever, G. Eglinton, R. Garrison, M. Greenberg, E. H. Paz, P. Hill, M. Ibaraki, M. Kastner, A. E. S. Kemp, K. Kvenvolden, R. Langridge, N. Lindsley-Griffin, J. Marsters, E. Martini, R. McCabe, L. Ocola, J. Resig, A. Q. SanchezFernandez, H.-J. Schrader, T. Thornburg, G. Wefer and M. Yamano (College Station: Ocean Drilling Program), 305-362.

Shipboard Scientific Party. (1988c). "Site 685," in Proceedings of the Ocean Drilling Program, Initial Reports 112, eds E. Suess, R. von Huene, K.-C. Emeis, J. Bourgois, J. d. C. CruzadoCastañeda, P. De Wever, G. Eglinton, R. Garrison, M. Greenberg, E. H. Paz, P. Hill, M. Ibaraki, M. Kastner, A. E. S. Kemp, K. Kvenvolden, R. Langridge, N. Lindsley-Griffin, J. Marsters, E. Martini, R. McCabe, L. Ocola, J. Resig, A. Q. SanchezFernandez, H.-J. Schrader, T. Thornburg, G. Wefer and M. Yamano (College Station: Ocean Drilling Program), 597-704.

Shipboard Scientific Party. (1992a). "Site 851b," in Proceedings of the Ocean Drilling Program, Initial Reports 138 (Pt. 2), eds L. Mayer, N.
G. Pisias, T. R. Janecek, J. G. Baldauf, S. F. Bloomer, K. A. Dadey, K.-C. Emeis, J. Farrell, J. A. Flores, E. M. Galimov, T. K. Hagelberg, P. Holler, S. A. Hovan, M. Iwai, A. E. S. Kemp, D. C. Kim, G. Klinkhammer, M. Leinen, S. Levi, M. A. Levitan, M. W. Lyle, A. K. MacKillop, L. M. Meynadier, A. C. Mix, T. C. Moore, I. Raffi, C. Ravelo, D. Schneider, N. J. Shackleton, J.-P. Valet and E. Vincent (College Station: Ocean Drilling Program), 891-965.

Shipboard Scientific Party. (1992b). "Site 846," in Proceedings of the Ocean Drilling Program, Initial Reports 138 (Pt. 1) eds L. Mayer, N. G. Pisias, T. R. Janecek, J. G. Baldauf, S. F. Bloomer, K. A. Dadey, K.-C. Emeis, J. Farrell, J. A. Flores, E. M. Galimov, T. K. Hagelberg, P. Holler, S. A. Hovan, M. Iwai, A. E. S. Kemp, D. C. Kim, G. Klinkhammer, M. Leinen, S. Levi, M. A. Levitan, M. W. Lyle, A. K. MacKillop, L. M. Meynadier, A. C. Mix, T. C. Moore, I. Raffi, C. Ravelo, D. Schneider, N. J. Shackleton, J.-P. Valet and E. Vincent (College Station: Ocean Drilling Program), 265-333.

Shipboard Scientific Party. (2000a). "Site 1143," in Proceedings of the Ocean Drilling Program, Initial Reports 184, eds P. Wang, W. L. Prell, P. Blum, E. M. Arnold, C. J. Bühring, M.-P. Chen, S. C. Clemens, P. D. Clift, C. J. G. Colin, J. W. Farrell, M. J. Higginson, Z. Jian, W. Kuhnt, C. E. Laj, C. Lauer-Leredde, J. S. Leventhal, A. Li, Q. Li, J. Lin, K. McIntyre, C. R. Miranda, S. A. Nathan, J.-P. Shyu, P. A. Solheid, X. Su, F. Tamburini, A. Trentsaux and L. Wang (College Station: Ocean Drilling Program), 1-103.

Shipboard Scientific Party. (2000b). "Site 1148," in Proceedings of the Ocean Drilling Program, Initial Reports 184, eds P. Wang, W. L. Prell, P. Blum, E. M. Arnold, C. J. Bühring, M.-P. Chen, S. C. Clemens, P. D. Clift, C. J. G. Colin, J. W. Farrell, M. J. Higginson, Z. Jian, W. Kuhnt, C. E. Laj, C. Lauer-Leredde, J. S. Leventhal, A. Li, Q. Li, J. Lin, K. McIntyre, C. R. Miranda, S. A. Nathan, J.-P. Shyu, P. A. Solheid, X. Su, F. Tamburini, A. Trentsaux, and L. Wang (College Station: Ocean Drilling Program), 1-121.

Shipboard Scientific Party. (2003a). "Site 1225," in Proceedings of the Ocean Drilling Program, Initial Reports 201, eds S. D’Hondt, B. B. Jørgensen, D. J. Miller, I. W. Aiello, B. Bekins, R. Blake, B. A. Cragg, H. Cypionka, G. R. Dickens, T. Ferdelman, K. Ford, G. L. Gettemy, G. Guerin, K.-U. Hinrichs, N. Holm, C.
House, F. Inagaki, P. Meister, R. M. Mitterer, T. Naehr, S. Niitsuma, J. R. Parkes, A. Schippers, C. G. Skilbeck, D. C. Smith, A. J. Spivack, A. Teske and J. Wiegel (College Station: Ocean Drilling Program), 1-86.

Shipboard Scientific Party. (2003b). "Site 1226," in Proceedings of the Ocean Drilling Program, Initial Reports 201, eds S. D’Hondt, B. B. Jørgensen, D. J. Miller, I. W. Aiello, B. Bekins, R. Blake, B. A. Cragg, H. Cypionka, G. R. Dickens, T. Ferdelman, K. Ford, G. L. Gettemy, G. Guerin, K.-U. Hinrichs, N. Holm, C. House, F. Inagaki, P. Meister, R. M. Mitterer, T. Naehr, S. Niitsuma, J. R. Parkes, A. Schippers, C. G. Skilbeck, D. C. Smith, A. J. Spivack, A. Teske, and J. Wiegel (College Station: Ocean Drilling Program), 1-96.

Shipboard Scientific Party. (2003c). "Site 1227," in Proceedings of the Ocean Drilling Program, Initial Reports 201, eds S. D'Hondt, B. B. Jørgensen, D. J. Miller, I. W. Aiello, B. Bekins, R. Blake, B. A. Cragg, H. Cypionka, G. R. Dickens, T. Ferdelman, K. Ford, G. L. Gettemy, G. Guerin, K.-U. Hinrichs, N. Holm, C. House, F. Inagaki, P. Meister, R. M. Mitterer, T. Naehr, S. Niitsuma, J. R. Parkes, A. Schippers, C. G. Skilbeck, D. C. Smith, A. J. Spivack, A. Teske, and J. Wiegel (College Station: Ocean Drilling Program), 1-66.

Shipboard Scientific Party. (2003d). "Site 1229," in Proceedings of the Ocean Drilling Program, Initial Reports 201, eds S. D’Hondt, B. B. Jørgensen, D. J. Miller, I. W. Aiello, B. Bekins, R. Blake, B. A. Cragg, H. Cypionka, G. R. Dickens, T. Ferdelman, K. Ford, G. L. Gettemy, G. Guerin, K.-U. Hinrichs, N. Holm, C. House, F. Inagaki, P. Meister, R. M. Mitterer, T. Naehr, S. Niitsuma, J. R. Parkes, A. Schippers, C. G. Skilbeck, D. C. Smith, A. J. Spivack, A. Teske, and J. Wiegel, (College Station: Ocean Drilling Program), 1-78.

Shipboard Scientific Party. (2003e). "Site 1230," in Proceedings of the Ocean Drilling Program, Initial Reports 201, eds S. D’Hondt, B. B. Jørgensen, D. J. Miller, I. W. Aiello, B. Bekins, R. Blake, B. A. Cragg, H. Cypionka, G. R. Dickens, T. Ferdelman, K. Ford, G. L. Gettemy, G. Guerin, K.-U. Hinrichs, N. Holm, C. House, F. Inagaki, P. Meister, R. M. Mitterer, T. Naehr, S. Niitsuma, J. R. Parkes, A. Schippers, C. G. Skilbeck, D. C. Smith, A. J. Spivack, A. Teske, and J. Wiegel (College Station: Ocean Drilling Program), 1-107.

Shipboard Scientific Party. (2003f). "Site 1231," in Proceedings of the
Ocean Drilling Program, Initial Reports 201, eds S. D’Hondt, B. B. Jørgensen, D. J. Miller, I. W. Aiello, B. Bekins, R. Blake, B. A. Cragg, H. Cypionka, G. R. Dickens, T. Ferdelman, K. Ford, G. L. Gettemy, G. Gierin, K.-U. Hinrichs, N. Holm, C. House, F. Inagaki, P. Meister, R. M. Mitterer, T. Naehr, S. Niitsuma, J. R. Parkes, A. Schippers, C. G. Skilbeck, D. C. Smith, A. J. Spivack, A. Teske, and J. Wiegel (College Station: Ocean Drilling Program), 1-64.

Shipboard Scientific Party. (2003g). "Site 1244," in Proceedings of the Ocean Drilling Program, Initial Reports 204, eds A. M. Tréhu, G. Bohrmann, F. R. Rack, M. E. Torres, N. L. Bangs, S. R. Barr, W. S. Borowski, G. E. Claypool, T. S. Collett, M. E. Delwiche, G. R. Dickens, D. S. Goldberg, E. Gràcia, G. Guérin, M. Holland, J. E. Johnson, Y.-J. Lee, C.-S. Liu, P. E. Long, A. V. Milkov, M. Riedel, P. Schultheiss, X. Su, B. Teichert, H. Tomaru, M. Vanneste, M. Watanabe and J. L. Weinberger (College Station: Ocean Drilling Program), 1-132.

Shipboard Scientific Party. (2003h). "Site 1245," in Proceedings of the Ocean Drilling Program, Initial Reports 204, eds A. M. Tréhu, G. Bohrmann, F. R. Rack, M. E. Torres, N. L. Bangs, S. R. Barr, W. S Borowski, G. E. Claypool, T. S. Collett, M. E. Delwiche, G. R. Dickens, D. S. Goldberg, E. Grácia, G. Guérin, M. Holland, J. E. Johnson, Y.-J. Lee, C.-S. Liu, P. E. Long, A. V. Milkov, M. Riedel, P. Schultheiss, X. Su, B. Teichert, H. Tomaru, M. Vanneste, M. Watanabe and J. L. Weinberger (College Station: Ocean Drilling Program), 1-131.

Shipboard Scientific Party. (2003i). "Site 1251," in Proceedings of the Ocean Drilling Program, Initial Reports 204, eds A. M. Tréhu, G. Bohrmann, F. R. Rack, M. E. Torres, N. L. Bangs, S. R. Barr, W. S. Borowski, G. E. Claypool, T. S. Collett, M. E. Delwiche, G. R. Dickens, D. S. Goldberg, E. Gràcia, G. Guérin, M. Holland, J. E. Johnson, Y.-J. Lee, C.-S. Liu, P. E. Long, A. V. Milkov, M. Riedel, P. Schultheiss, X. Su, B. Teichert, H. Tomaru, M. Vanneste, M. Watanabe and J. L. Weinberger (College Station: Ocean Drilling Program), 1-119.

Sørensen, K. B., Lauer, A., and Teske, A. (2004). Archaeal phylotypes in a metal-rich and low-activity deep subsurface sediment of the Peru Basin, ODP Leg 201, Site 1231. Geobiology 2, 151-161.

Sørensen, K. B., and Teske, A. (2006). Stratified communities of active 
Archaea in deep marine subsurface sediments. Appl. Environ. Microbiol. 72, 4596-4603.

Spear, J. R., Walker, J. J., McCollom, T. M., and Pace, N. R. (2005). Hydrogen and bioenergetics in the Yellowstone geothermal ecosystem. Proc. Natl. Acad. Sci. U.S.A. 102, 2555-2560.

Sundset, M. A., Edwards, J. E., Cheng, Y. F., Senosiain, R. S., Fraile, M. N., Northwood, K. S., Praesteng, K. E., Glad, T., Mathiesen, S. D., and Wright, A.-D. G. (2009). Rumen microbial diversity in Svalbard reindeer, with particular emphasis on methanogenic archaea. FEMS Microbiol. Ecol. 70, 553-562.

Takai, K., and Horikoshi, K. (1999). Genetic diversity of Archaea in deep-sea hydrothermal vent environments. Genetics 152, 1285-1297.

Takai, K., and Horikoshi, K. (2000). Rapid detection and quantification of members of the archaeal community by quantitative PCR using fluorogenic probes. Appl. Environ. Microb. 66, 5066-5072.

Takai, K., Moser, D. P., DeFlaun, M., Onstott, T. C., and Fredrickson, J. K. (2001). Archaeal diversity in waters from deep South African gold mines. Appl. Environ. Microbiol. 67, 5750-5760.

Tao, L., Peng, W., and Pinxian, W. (2008). Microbial diversity in surface sediments of the Xisha Trough, the South China Sea. Acta Ecol. Sin. 28, 1166-1173.

Teske, A. (2006). Microbial communities of deep marine subsurface sediments: molecular and cultivation surveys. Geomicrobiol. J. 23, 357-368.

Teske, A., Hinrichs, K.-U., Edgcomb, V., de Vera Gomez, A., Kysela, D., Sylva, S. P., Sogin, M. L., and Jannasch, H. W. (2002). Microbial diversity of hydrothermal sediments in the Guaymas Basin: evidence for anaerobic methanotrophic communities. Appl. Environ. Microbiol. 68, 1994-2007.

Teske, A., and Sørensen, K. B. (2008). Uncultured archaea in deep marine subsurface sediments: have we caught them all? ISME J. 2, 3-18.

Thamdrup, B. (2000). "Bacterial manganese and iron reduction in aquatic sediments," in Advances in Microbial Ecology, Vol. 16, ed. B. Schink (New York: Kluwer Academic), 41-81.

Urrutia, M. M., Roden, E. E., Fredrickson, J. K., and Zachara, J. M. (1998). Microbial and surface chemistry controls on reduction of synthetic $\mathrm{Fe}$ (III) oxide minerals by the dissimilatory iron-reducing bacterium Shewanella alga. Geomicrobiol. J. 15, 269-291.

Urrutia, M. M., Roden, E. E., and Zachara, J. M. (1999). Influence of aqueous and solid-phase Fe(II) complexants on microbial reduction of crystalline iron(III) oxides. Environ. Sci. Technol. 33, 4022-4028.

Van der Wielen, P. W., Bolhuis, H., Borin, S., Daffonchio, D., Corselli, C., Giuliano, L., D’Auria, G., de Lange, G. J., Huebner, A., Varnavas, S. P., Thomson, J., Tamburini, C., Marty, D., McGenity, T. J., Timmis, K. N., and BioDeep Scientific Party. (2005). The enigma of prokaryotic life in deep hypersaline anoxic basins. Science 307, 121-123.

Vetriani, C., Jannasch, H. W., MacGregor, B. J., Stahl, D. A., and Reysenbach, A.-L. (1999). Population structure and phylogenetic characterization of marine benthic archaea in deep-sea sediments. Appl. Environ. Microbiol. 65, 4375-4384.

von Mering, C., Hugenholtz, P., Tringe, S. G., Doerks, T., Jensen, L. J., Ward, N., and Bork, P. (2007). Quantitative phylogenetic assessment of microbial communities in diverse environments. Science 315, 1126-1130.

Wakeham, S. G., Lee, C., Hedges, J. I., Hernes, P. J., and Peterson, M. L. (1997). Molecular indicators of diagenetic status in marine organic matter. Geochim. Cosmochim. Acta 61, 5363-5369.

Wang, G., Spivack, A. J., Rutherford, S., Manor, U., and D'Hondt, S. (2008).
Quantification of co-occurring reaction rates in deep subseafloor sediments. Geochim. Cosmochim. Acto 72, 3479-3488.

Wang, P., Li, T., Hu, A., Wei, Y., Guo, W., Jiao, N., and Zhang, C. (2010a). Community structure of archaea from deep-sea sediments of the South China Sea. Microb. Ecol. 60, 796-806.

Wang, G., Spivack, A. J., and D'Hondt, S. (2010b). Gibbs energies of reaction and microbial mutualism in anaerobic deep subseafloor sediments of ODP Site 1226 Geochim. Cosmochim. Acta 74 3938-3947.

Wang, P., Wang, F., Xu, M., and Xiao, X. (2004). Molecular phylogeny of methylotrophs in a deep-sea sediment from a tropical west Pacific Warm Pool. FEMS Microbiol. Ecol. 47, 77-84.

Wang, P., Xiao, X., and Wang, F. (2005). Phylogenetic analysis of Archaea in the deep-sea sediments of west Pacific Warm Pool. Extremophiles 9, 209-217.

Wellsbury, P., Mather, I., and Parkes, R. J. (2002). Geomicrobiology of deep, low organic carbon sediments in the Woodlark Basin, Pacific Ocean. FEMS Microbiol. Ecol. 42, 59-70.

Whitman, J. M., and Davis, T. A (1979). Cenozoic oceanic sedimentation rates: how good are the data? Mar. Geol. 30, 296-284.

Whitman, W. B., Coleman, D. C., and Wiebe, W. J. (1998). Prokaryotes: the unseen majority. Proc. Natl. Acad. Sci. U.S.A. 95, 6578-6583.

Wright, A.-D. G., and Pimm, C. (2003). Improved strategy for presumptive identification of methanogens using 16S riboprinting. J. Microbiol. Methods 55, 337-349.

$\mathrm{Xu}$, M., Wang, P., Wang, F., and Xiao, X. (2005). Microbial diversity at a deep-sea station of the Pacific nodule province. Biodivers. Conserv. 14, 3363-3380.

Zheng, D., Alm, E. W., Stahl, D. A., and Raskin, L. (1996). Characterization of universal small-subunit rRNA hybridization probes for quantitative molecular microbial ecology studies. Appl. Environ. Microbiol. 62, 4504-4513.

Zhou, J., Bruns, M. A., and Tiedje, J. M. (1996). DNA recovery from soils of diverse composition. Appl. Environ. Microbiol. 62, 316-322.

Ziebis, W., McManus, J., Ferdelman, T. G., Schmidt-Schierhorn, F., Bach, W., Muratli, J., Edwards, K. J., and Villinger, H. (2012). Interstitial fluid chemistry of sediments underlying the North Pond Atlantic Gyre and the influence of subsurface fluid flow. Earth Planet. Sci. Lett. 323-324, 79-91.

Zinger, L, Amaral-Zettler, L. A., Fuhrman, J. A., Horner-Devine, M. C., Huse, S. M., Mark Welch, D. B., Martiny, J. B. H., Sogin, M. Boetius, A., and Ramette, A. (2011). Global patterns of bacterial betadiversity in seafloor and seawater ecosystems. PLOS ONE 6, e24570. doi:10.1371/journal.pone.0024570

Conflict of Interest Statement: The authors declare that the research was conducted in the absence of any commercial or financial relationships that could be construed as a potential conflict of interest.

Received: 30 January 2012; accepted: 16 April 2012; published online: 31 May 2012.

Citation: Durbin AM and Teske A (2012) Archaea in organic-lean and organic-rich marine subsurface sediments: an environmental gradient reflected in distinct phylogenetic lineages. Front. Microbio. 3:168. doi: 10.3389/fmicb.2012.00168

This article was submitted to Frontier in Extreme Microbiology, a specialty of Frontiers in Microbiology.

Copyright $\odot 2012$ Durbin and Teske. This is an open-access article distributed under the terms of the Creative Commons Attribution Non Commercial License, which permits non-commercial use, distribution, and reproduction in other forums, provided the original authors and source are credited. 